\title{
WHEN THE CLAIM HITS \\ Bilateral Investment Treaties and Bounded \\ Rational Learning
}

\author{
By LAUGE N. SKOVGAARD POULSEN and EMMA AISBETT*
}

\section{INTRODUCTION}

B ILATERAL investment treaties (BITs) have in recent years been B presented as among the most potent legal instruments underwriting economic globalization. ${ }^{1}$ The treaties grant foreign investors a right to file international arbitration claims directly against governments without first needing to exhaust local remedies. If governments refuse to participate in the proceedings or chose not to comply with an arbitral award, investors are allowed to confiscate their commercial property in most corners of the world, with only limited options for courts in the enforcing states to refuse execution. Combined with their wide scope of administrative review, this dispute-settlement mechanism makes BITs uniquely powerful in the context of international law. As foreign investors have come to realize over the last decade and a half, developing country governments, in particular, have found themselves on the respondent end of an increasing number of investment treaty arbitrations that have resulted in awards of hundreds of millions of dollars and often involved sensitive areas of public regulation. Thus, it has become increasingly clear that adopting BITs entails considerable risk.

But while almost every developing country has adopted at least a few BITs, the question is whether they truly realized that by consenting to investment treaty arbitration, they were exposing themselves to the risk of costly litigation. Almost all studies of BIT formation are based

\footnotetext{
*The authors would like to thank Anna Joubin-Bret, Mark Kantor, Edmund Malesky, Mark Manger, Andrew Walter, Lou Wells, Kurt Weyland, and Stephen Woolcock, as well as three reviewers and the editors of World Politics, for helpful comments and assistance. Thanks are also due to participants at staff seminars at the Department of Business and Politics, Copenhagen Business School, and the Crawford School of Economics and Government, Australian National University, for insightful comments. All errors remain our own.

${ }^{1}$ E.g., Van Harten 2007; Schneiderman 2008; Montt 2009; Schill 2009.
}

World Politics 65, no. 2 (April 2013), 273-313

Copyright (C) 2013 Trustees of Princeton University doi: S0043887113000063 
on the assumption that developing countries understood the potential costs of the treaties at the time the modern network of BITs was established during the 1990s. ${ }^{2}$ But when BITs with investor-state arbitration clauses were proliferating rapidly, there were as yet few claims indicating that they actually had a tangible impact on investor-state relations.

The rise in investment treaty claims has therefore led to spatially and temporally dispersed arrival of important information about the potential costs of BITs. Combined with the fact that participation is a repeated decision for states, this provides a unique opportunity to study not only how governments have responded to the rise of investment arbitrations but also, more broadly, how they learn about the impact of their (economic) policies.

The latter question has been dealt with in the literature on policy learning, which seeks to understand the processes whereby policymakers change beliefs as a result of observing and interpreting experiences, which in turn may lead to corresponding policy changes. ${ }^{3}$ The most prominent learning model in this literature is Bayesian updating, where governments learn about policies by weighing their prior beliefs (for example, the prudence of signing BITs) against the quantity and quality of observed experience (for example, the liabilities involved in investment treaty arbitration). ${ }^{4}$ An alternative view of policy learning comes out of the literature on bounded rationality. Here, too, policymakers are seen as goal oriented and thereby rational in the broadest sense of the word. But rather than following the laws of statistics, policy learning is biased by cognitive shortcuts consistently found in experimental studies on human judgments and decision making. ${ }^{5}$

In the context of the international political economy (IPE) literature, as well as that of international relations more broadly, the second view on policy learning has received only scant attention. This may be appropriate, if models of bounded rationality sacrifice theoretical parsimony without leading to new and important insights. If, however, insights on bounded rationality can in fact most elegantly explain systematic variation in how countries learn about their economic policies,

\footnotetext{
${ }^{2}$ E.g., Guzman 1998; Elkins, Simmons, and Guzman 2006, 825; Montt 2009, 128; Blake 2010; Büthe and Milner 2009; Allee and Peinhardt 2010; Bergstrand and Egger 2011. For exceptions, see Van Harten 2010, 42-46; Jandhyala, Henisz, and Mansfield 2011. Note that BITs were signed from the late 1950s, but only from the late 1980s did most include a legally binding consent to investor-state arbitration; Yackee 2008.

${ }^{3}$ E.g., Levy 1994.

4 "Quality" here refers to the variability, or consistency, of available outcome information. See, generally, Meseguer 2009.

${ }^{5}$ See, generally, Jones and Baumgartner 2005.
} 
perhaps it is time to include them in the standard theoretical arsenal of the international relations literature.

To contribute to this question, the BIT regime provides an excellent case study. First, in contrast to the diffusion of revolutions and other path-breaking policy innovations recently studied from a bounded rationality perspective by Kurt Weyland, ${ }^{6}$ the decision to enter into BITs has not been a one-off event for the individual country, but rather has been a sequential, or evolutionary, process that unfolds over decades. The time pressure has been minimal, and if states were not satisfied with their initial decision, they did not have to continue since they had not been coerced into joining the BIT movement. ${ }^{7}$ This makes the BIT movement a hard case for a bounded rationality framework.

Second, while some foreign policy studies in the security realm have applied insights on bounded rationality, ${ }^{8}$ the politics of investment treaties is not characterized by the same degree of pressure and emotions as are found in military conflict, and actors are therefore less prone to be influenced by biasing heuristics. For this reason as well, the BIT movement is a hard case.

Third, Meseguer has argued, convincingly, that applying bounded rationality insights to the study of international economic policies does not necessarily lead to predictions that could not be explained just as well by a Bayesian framework. ${ }^{9}$ Yet we will show that the bilateral nature of BITs offers a quantifiable prediction of the bounded rational learning model that is not observationally equivalent to that of Bayesian learning.

The article is divided into four sections. Based on the observation that BITs involve high-impact, low-probability costs, the first section will outline our two main competing hypotheses based on rational learning and bounded rational learning. The second will present qualitative insights from interviews with policymakers as to whether and how the rise of investment treaty arbitration had an impact on the willingness of developing countries to enter into BITs. We focus on developing countries, as they have been subject to the vast majority of disputes. ${ }^{10}$ Building on these insights, the third section offers an econometric analysis of the impact of investment arbitrations on the

\footnotetext{
${ }^{6}$ Weyland 2006; Weyland 2009; Weyland 2010.

${ }^{7}$ Alvarez 2011, chap. 2.

${ }^{8}$ Jervis 1976; Reiter 1996; Vertzberger 1998.

${ }^{9}$ Meseguer 2006.

${ }^{10}$ As discussed in the conclusion, the learning process could very well have been different for developed countries.
} 
propensity of developing countries to adopt BITs. Both the qualitative and the quantitative evidence suggests that many developing country officials have been bounded rational when learning about BITs by ignoring the risks of BITs until they were hit by their first claim. The fourth section considers two potential alternative explanations for the behavior we observe. Most importantly, this leads us to identify a prediction that is unique to a bounded rationality approach and to test it using an augmented version of the data set from Elkins, Guzman, and Simmons's (EGS) highly influential paper on BIT diffusion. ${ }^{11}$ Finally, we conclude by discussing the relevance of our evidence not only for studies of the investment regime but also for other areas of IPE.

Before proceeding, however, it is important to stress that although the article offers important hints as to why developing countries signed BITs-some of which seriously question underlying assumptions in existing accounts - this is not its main aim. Rather than offering a general account of the BIT movement, we use it as a case study to understand the broader question of how governments process information about the implications of their economic policies.

\section{LeARning ABOUt High-Impact, Low-Probability Events: The Case of Investment Treaty Arbitration}

The starting point for our analysis of policy learning is the observation that as the number of investment treaty arbitrations has grown, BIT participation has slowed down considerably (Figure 1). ${ }^{12}$ While we know that the claims have led some countries to clarify and restrict the scope of their BITs - as even developed countries have been surprised about the potential breadth of key BIT standards ${ }^{13}$ - we ask a simpler question, namely, how has the rise of investment treaty arbitration affected governments' decisions to participate in BITs.

Is it a coincidence that the rush to sign BITs slowed down as the treaties' adjudication mechanism became operational in practice? ${ }^{14}$ And if

${ }^{11}$ EGS 2006.

${ }^{12}$ The exception is 2001, which is likely due to UNCTAD's intense promotion of investment treaties that year. It resulted in more than seventy signed at various "signing sessions"; UNCTAD 2002. The slowdown is clear also if one considers that some countries today prefer free trade agreements with investment chapters over BITs: in 2008, for instance, only seven investment protection treaties other than BITs were signed, bringing the total number of investment treaties up to eighty-one-fewer than half the number signed just ten years before.

${ }^{13}$ UNCTAD 2007; Yannacka-Small 2008, fn. 9 ("As was the case with the majority of BIT provisions, second thoughts only began to arise when arbitral tribunals began to shed light on these provisions.”)

${ }^{14}$ Aaken 2010, 550. 


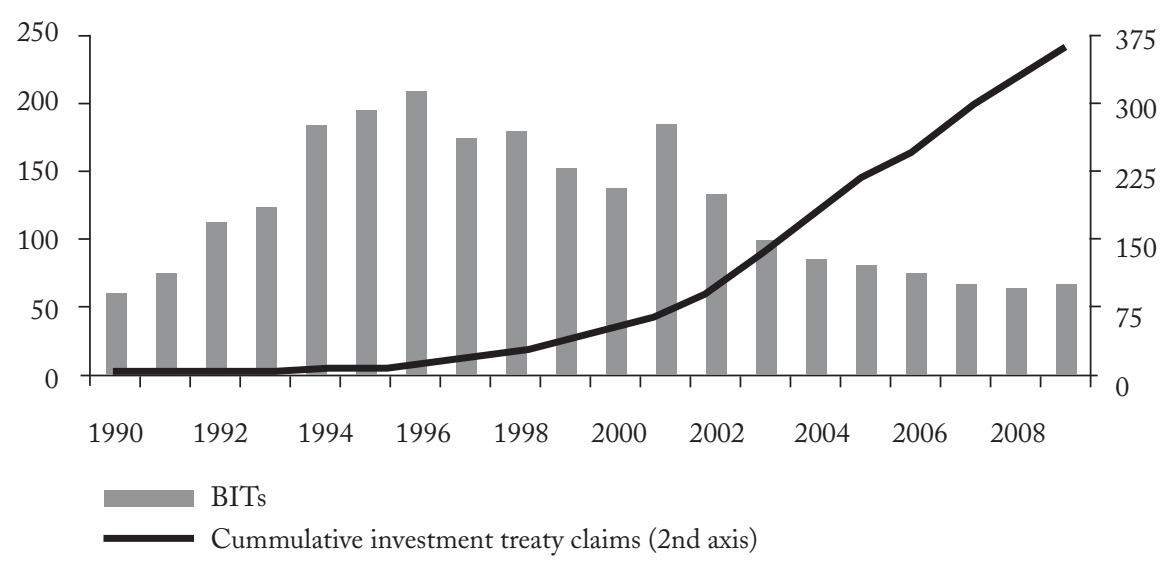

Figure 1

BITs Signed Per Year and Total Number of BIT Claims ${ }^{a}$

SOURCE: UNCTAD.

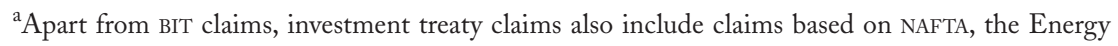
Charter Treaty, and other investment treaties. By far the majority are BIT claims.

it is not merely a result of saturation of relevant treaties to be signed, ${ }^{15}$ how have developing country governments processed the information about the risks of BITs revealed by the claims?

In order to understand whether and how the rise in arbitration claims has made countries learn about the risks of BITs, we first need to consider the nature of those risks. For while BITs have exposed some countries to costly arbitration proceedings with sometimes farreaching ramifications, the probability that a given treaty would result in a claim was, until recently, very small. When modern BITs diffused rapidly during the 1990s, the decision to enter into the treaties was thereby an example of a policy that entailed costs with a high impact but a low probability.

When faced with low-probability events, a rational learner would be particularly careful to factor in the experiences of others. Per definition, low-probability events are unlikely to be part of a decision maker's immediate past experiences. And since the costs of ignoring information are larger if it is the only information available, this makes decision makers' own experiences with low-probability events the "teacher

${ }^{15}$ This has been suggested by Saban, Bonomo, and Stier-Moses 2010. 
of fools." ${ }^{16}$ So whether policy learning is a horizontal process - that is, learning directly from other countries - or whether it is channeled through intermediaries, such as international organizations, ${ }^{17}$ a rational government should carefully consider information revealed about the risks of BITs when it sees other countries become subject to investment treaty disputes.

An alternative explanation for the slowdown in BIT participation comes out of the bounded rationality literature. This suggests that rather than considering all relevant and available information, decision makers tend to rely mostly on whatever information is salient at a given time. ${ }^{18}$ So although information was easily available to developing countries about claims against other countries, ${ }^{19}$ learning about the potential costs of the treaties may have been skewed by the application of the "availability heuristic." This refers to the tendency of people to evaluate the probability of events based on the ease with which relevant instances come to mind. ${ }^{20}$ While obviously a useful cognitive shortcut in many instances, this can also have a biasing impact on people's judgments and behavior, as it may lead to ignoring information that is relevant and attaching great value to some that is not. ${ }^{21}$

The availability heuristic is particularly important in cases such as ours because people tend to show bimodal responses to low-probability events: some greatly exaggerate them, and others assume they can ignore them completely, with the choice between the two reactions depending on the extent to which people can bring specific and "vivid" instances to mind. ${ }^{22}$ In the absence of highly "available" information, decision makers often fail to give low-probability events due consideration until lightning strikes. ${ }^{23}$ As hinted at above, this implies that while "muddling through" and "satisficing" may often be useful for

${ }^{16}$ March 2010.

${ }^{17}$ E.g., Simmons, Dobbin, and Garrett 2006, 797-98.

${ }^{18}$ E.g., Weyland 2006.

${ }^{19}$ Most claims have been pursued under ICSID, where the secretariat continuously kept its members informed about disputes before the center both through publications as well as its technical advice. The United Nations also regularly sent out publications to member states on the potency of international investment agreements; for example, UNCTC 1988; UNCTAD 1998; UNCTAD 1999. Note also that while BIT claims began in the late 1980s/early 1990s, nonstate actors have occasionally used international law to pursue compensation claims against host governments since the interwar period; see, generally, Parlett 2011, chap. 2.

${ }^{20}$ Tversky and Kahneman 1973. See also Simmons, Dobbin, and Garrett 2006; Weyland 2006; Weyland 2009; and Weyland 2010.

${ }^{21}$ Johnson et al. 2000.

${ }^{22}$ McClelland, Schulze, and Coursey 1993; Slovic et al. 2000; Slovic, Fischhoff, and Lichtenstein 2000a.

${ }^{23}$ Camerer and Kunreuther 1989; Kunreuther et al. 2002. 
bounded rational actors, they are particularly imprudent decision strategies when learning about low-probability events as it can lead to optimism bias. ${ }^{24}$ For instance, just as repeated safe driving experiences can lead people not to wear seat belts if they fail to consider the experiences of others, ${ }^{25}$ an absence of investment treaty claims against a government in the past could lead to the misunderstanding that BITs may be far-reaching in theory but entail no risks in practice.

This is an important difference in the predictions of the two perspectives on policy learning: whereas rational policymakers are expected to learn from all relevant experiences, policymakers who apply inferential shortcuts when interpreting information are expected to learn much more from their own experiences, as that information is more readily available. This type of "narcissistic learning" is therefore our second hypothesis for why we observe a slowdown in BIT participation. Just as individuals tend to insure against low-probability events after they have already been injured themselves, ${ }^{26}$ developing countries may have displayed similar behavior in the investment regime by seriously considering the risks of BITs only after having been subject to a BIT claim themselves. Moreover, rather than merely underestimating the risks of BITs due to imperfect information, as could be explained by Bayesian learning, a bounded rationality framework implies that risks were entirely ignored until a claim hit.

Below we consider these two main hypotheses based on both microlevel evidence in the form of a case study and survey data, as well as macrolevel quantitative evidence.

\section{Qualitative Evidence}

\section{The Case of Pakistan}

As a first cut to investigate just how developing countries have learned about the implications of the investment treaty policies, we begin by briefly reviewing the case of Pakistan. Pakistan is useful for our purposes as it has participated in BITs for half a century, since it signed the first ever treaty BIT with Germany in 1959. Also, Pakistan has signed numerous BITs since the early 1990s, which allow investors direct

\footnotetext{
${ }^{24}$ Camerer and Kunreuther 1989; Slovic, Kunreuther, and White 2000, 27. On the relationship between the availability heuristic and the discounting of distant risks, see also work on construal-level theory: Wakslak and Trope 2009; and Highhouse, Mohammed, and Hoffman 2010. For a recent application in international relations, see Krebs and Rapport 2012.

${ }^{25}$ Slovic, Fischhoff, and Lichtenstein 2000b.

${ }^{26}$ Steinbrugge, McClure, and Snow 1969.
} 
recourse to investor-state arbitration. Governments in Pakistan have thereby had more than ample opportunity to learn about the implications of such treaties.

The first treaty-based investor-state arbitration against Pakistan was filed by a Swiss investor in 2001. ${ }^{27}$ But while several investment treaty claims had been filed up through the 1990s questioning a wide range of government conduct, and Pakistan had been made explicitly aware of the potency of the treaties, ${ }^{28}$ the claim in 2001 took everyone within the Pakistani bureaucracy by complete surprise. When learning of the dispute, Pakistan's attorney general - one of the top experts on international public law in South Asia - actually had to look up "BITs" and "ICSID" on Google. And when inquiring with the relevant ministries, there were almost no records of Pakistan's past BIT negotiations with Switzerland. There were no files or documentation in any of the responsible ministries and no indication that the treaty had ever been discussed in Parliament. In fact, the treaty itself was nowhere to be found, and the government had to request a copy from Switzerland through formal channels. For a legal instrument with such a considerable scope, this was somewhat of a mystery. The Swiss treaty was no exception, however, as hardly any records existed of Pakistan's earlier BIT negotiations. This was not because they were considered too sensitive to document in written form. On the contrary, numerous interviews with current and past officials involved in Pakistan's BIT negotiations confirm that when foreign delegations had come to the country or when the Pakistani leadership went abroad, BITs had merely been considered a piece of paper, something for the press - a token of goodwill. ${ }^{29}$ While there was an expectation that the treaties would lead to increased inflows of investment, government files today admit that occasionally "BITs were initially instruments that were signed during visits of high level delegations to provide for photo opportunities." 30 It was therefore not until Pakistan was hit by a multi-million-dollar arbitration claim that officials actually realized the implications of treaties signed by successive governments since 1959. In the following years, the Pakistani bureaucracy

\footnotetext{
${ }^{27}$ SGS Société Générale de Surveillance S.A. v. Islamic Republic of Pakistan, ICSID Case No. ARB/01/13.

${ }^{28}$ Apart from reports provided by international organizations (see fn. 19), even a major Pakistani newspaper ran a series of articles on investment treaties written by a senior ICSID official; Parra 1996.

${ }_{29}$ Apart from the former attorney general, interviews covered the Board of Investment, Pakistan's embassy in Washington, D.C., the Ministry of Industries and Production, the Ministry of Finance, the Ministry of Law, the Ministry of Foreign Affairs, the Reserve Bank, and the Securities and Exchange Commission. Interviews were conducted in Lahore, Karachi, and Islamabad, January 2009 to August 2010.

${ }^{30}$ Communication between Pakistan's Board of Investment and Ministry of Law concerning renegotiation of German-Pakistan BIT, November 23, 2009. On file with the authors.
} 
blocked numerous ongoing negotiations, including one with the United States. And while some embassies, politicians, and investment-promotion officials are still pushing for Pakistan to sign BITs, some corners of the bureaucracy are now seeking to ensure that the government is fully aware that the treaties involve serious and far-reaching obligations. This politicization of BITs is a first in Pakistan's history.

The case of Pakistan thereby provides preliminary evidence in support of our bounded rational learning hypothesis. It indicates that the risks of BITs were not just underestimated through the 1990s, as could potentially be explained by a Bayesian framework due to imperfect information. Rather, the risks look to have been ignored completely. And instead of Pakistan learning from the experiences of other countries, it took a claim against Pakistan itself for the bureaucracy to realize the potency of the treaties.

\section{A SuRVEY}

The experiences of Pakistan may of course be unique, so we proceed by surveying a broader sample of developing countries. From January 2009 to May 2011 thirty interviews were conducted with officials from thirteen developing countries (excluding Pakistan) from all corners of the world. By 2009, all countries had been respondents in at least one BIT claim. Table 1 lists key sample statistics from 1996, the year the BIT movement was at its peak. While spread over each region, sample countries are generally richer and had much larger inward and outward FDI stocks than most other developing countries. This is important, as the opposite pattern could have slanted the sample in favor of a bounded rationality explanation (for example, lack of expertise, lack of stake in the system; see also below).

Two types of officials were interviewed: negotiators and stakeholders, who themselves were involved in investment protection policies during the 1990s. ${ }^{31}$ The stakeholders were officials from government agencies whose discretion could be curtailed by BITs; they therefore had an incentive to take a somewhat cautious approach toward the treaties. All

\footnotetext{
${ }^{31}$ In most countries, the negotiation of BITs during the 1990s was done by very few officialstypically only one-as the treaties were almost completely "depoliticized." As one Latin American official noted:

during the 1990s, BITs were a very different animal than FTAs, the WTO, and other globalization instruments.... By contrast with FTA agreements, there was no legal review, control, or scrutiny to the content.... Often BIT negotiations have been done by a couple of guys; they sent it to parliament with no real discussion. . . Apart from a copy of the BIT in the negotiator's office no one was even aware how many BITs the country had in the 1990s. (Interview with Mexican official, London, May 26, 2010).
} 
TABLE 1

Descriptive Statistics of Developing Countries Where One or More OFFICIALS WERE INTERVIEWED, 1996 ${ }^{\mathrm{a}}$

\begin{tabular}{lccc}
\hline \hline & Share of Total (\%) & Average & Median \\
\hline Inward FDI Stock & & & \\
$\quad$ Sample & 24 & 13.52 & 6.35 \\
$\quad$ Developing Countries & 100 & 4.60 & 0.55 \\
Outward FDI Stock & & & \\
$\quad$ Sample & 28 & 4.20 & 0.73 \\
$\quad$ Developing Countries & 100 & 1.78 & 0.11 \\
GDP & 17 & 77.41 & \\
Sample & 100 & 41.77 & 23.34 \\
Developing Countries & & & 5.37 \\
\hline
\end{tabular}

SOURCES: UNCTAD; World Development Indicators.

${ }^{a}$ All figures are in current bn. USD. Sample covers four countries from Asia, five from Latin America, two from Eastern Europe, and two from Africa.

interviews were semistructured, with the overall theme being the countries' experiences with negotiating and ratifying investment treaties.

Practically all officials, including stakeholders, noted that they had been unaware of the far-reaching scope and implications of BITs during the 1990s, when the treaties proliferated. Although some did consider the standards on expropriation, for instance, few realized that the treaties had such a considerable reach and were enforceable not only in principle but also in fact. This contrasts with standard accounts of BIT diffusion, yet is not too surprising. The lack of disputes at the time is likely to have led developing countries - and others - to underestimate the risks of the treaties. However, officials did not simply underestimate the risks of disputes due to imperfect information. Many instead ignored such risks and thereby treated BITs as one out of a long list of diplomatic gestures without any practical implications apart from helping to attract foreign investment. In twelve out of thirteen countries where officials were interviewed, respondents thus noted that it was not until the first claim was filed against their country that stakeholders realized that BITs exposed them to serious liabilities (Table 2). In fact, in eight out of thirteen cases even negotiators did not realize that BITs involved far-reaching and enforceable obligations until their own country was hit by a claim. ${ }^{32}$ While learning did take place on

${ }^{32}$ Investment treaties with the United States and Canada were somewhat different, as they included liberalization provisions, the implications of which were quite clear to negotiators and stakeholders. 
occasion, for instance, through UNCTAD's training courses, the response from one East European negotiator was representative: "Negotiators really didn't know that the treaties had any bite in practice. They were neither aware of the costs or the fact that it could lead to arbitration." ${ }^{33}$ So was the response from the Dominican Republic, where it was the first claim against the country in 2007 that made officials realize the potency of BITs: "[T]his led to a complete halt in negotiations, as we became aware we are legally liable." 34

These findings are consistent with some of the few developing country experiences that have been publicly discussed. A senior official notes, for example, that until Thailand was first sued in 2004, "the realisation that an investor could invoke investor-state dispute settlement in a treaty was perhaps not fully appreciated." ${ }^{35}$ Similarly, in South Africa a recent government report notes that negotiators and stakeholders did not realize during the 1990s that the treaties had serious legal implications for the country, and it was not until South Africa came on the respondent end of a major claim in the early 2000s that the treaties were taken seriously. ${ }^{36}$ After that, senior officials in South Africa decided to considerably slow down the country's BIT participation, particularly with developed countries. ${ }^{37}$

Similarly, there are indications that countries that have not been subject to BIT disputes still have a much more haphazard BIT policy than those that have experienced them. For instance, in his case study of India - a country otherwise so careful to guard its sovereignty-Ranjan notes that since BITs had not had adverse implications for the country at the time of writing, stakeholders still assumed they had no impact on India's regulatory flexibility. ${ }^{38}$ And in the case of Libya, consider this report on the BIT signed with Spain during Qadhafi's visit there in 2007:

... the Government of Libya (GOL) indicated ... that it wished to quickly finalize language for an education and culture agreement, a defense cooperation agreement, a bilateral legal cooperation and extradition treaty, an investment security agreement and a double taxation-exemption agreement.... [A Spanish official, ed.] lamented that the rush to finalize agreements for signature in time for Qadhafi's visit had precluded meaningful bilateral discussions of what the

\footnotetext{
${ }^{33}$ Interview with Czech official, Copenhagen, April 28, 2010.

${ }^{34}$ Interview with Dominican Republic official, Copenhagen, May 17, 2011.

${ }^{35}$ Mangklatanakul 2011, 82.

${ }^{36}$ DTI 2010.

${ }^{37}$ See further in Poulsen 2014.

${ }^{38}$ Ranjan 2012. Since Ranjan's study, claims against India made the government put a hold on all ongoing BIT negotiations until a review of the country's BIT policy had been completed.
} 
benefit considerations but rather failed even to consider the risks of the treaties until they were hit by their first claim.

All in all, these qualitative findings provide supportive evidence for a bounded rational learning process. To further sustain this conclusion, we proceed by triangulating the qualitative findings with quantitative evidence on BIT participation.

\section{Quantitative Evidence}

Figure 2 uses an "event study" to provide a preliminary visual assessment of the hypothesis that participants responded principally to claims against themselves. The y-axis shows the average annual number of BITs signed or ratified by developing countries that have had at least one BIT-based claim brought to arbitration. The $\mathrm{x}$-axis shows time relative to the year of registration of the first BIT claim against the country in discrete (annual) intervals.

The pattern corresponds with the survey findings: while signing rates were already decreasing on average prior to the time of first claim, this downward trend amplified considerably after the claim was registered. Even more notable is that the upward trend in number of BITs ratified per year experiences a reversal in the year of the first claim. ${ }^{42}$

Yet, as supportive as Figure 2 is, we must still consider that the correlation between experience of a claim and decreased BIT participation may be spurious, driven by omitted variables such as global shocks, changing norms toward foreign investors and investment treaties, national political or economic environment, and participation dynamics (such as the exhaustion of treaty-partner possibilities). To address these concerns, we turn to the tools of econometrics. ${ }^{43}$

Our country-year panel data include observations for 138 developing or transition countries for the years 1990 to 2009. For our purposes, we understand a developing or transition economy (henceforth, merely referred to as developing countries) as one that the World Bank does not classify as a "high income" country for the majority of our sample

\footnotetext{
${ }^{42}$ Note that while it was irrational to entirely ignore the risks of BITs until hit by a claim, we are not arguing that the sizable drop in BIT participation is necessarily a rational response-in fact, a prediction from the bounded rationality literature would be that it could be overly drastic. Similarly, we are not arguing that entering into BITs is inherently irrational and therefore do not expect adoption to reach zero after the claim, particularly as developing countries are increasingly becoming capital exporters themselves and certain government agencies are bound to continue pushing for the treaties (cf. the case of Pakistan).

${ }^{43}$ The model proposed by Jandhyala, Henisz, and Mansfield 2011 is an example of an alternative explanation that is consistent with Figure 2 but cannot explain our regression results below.
} 


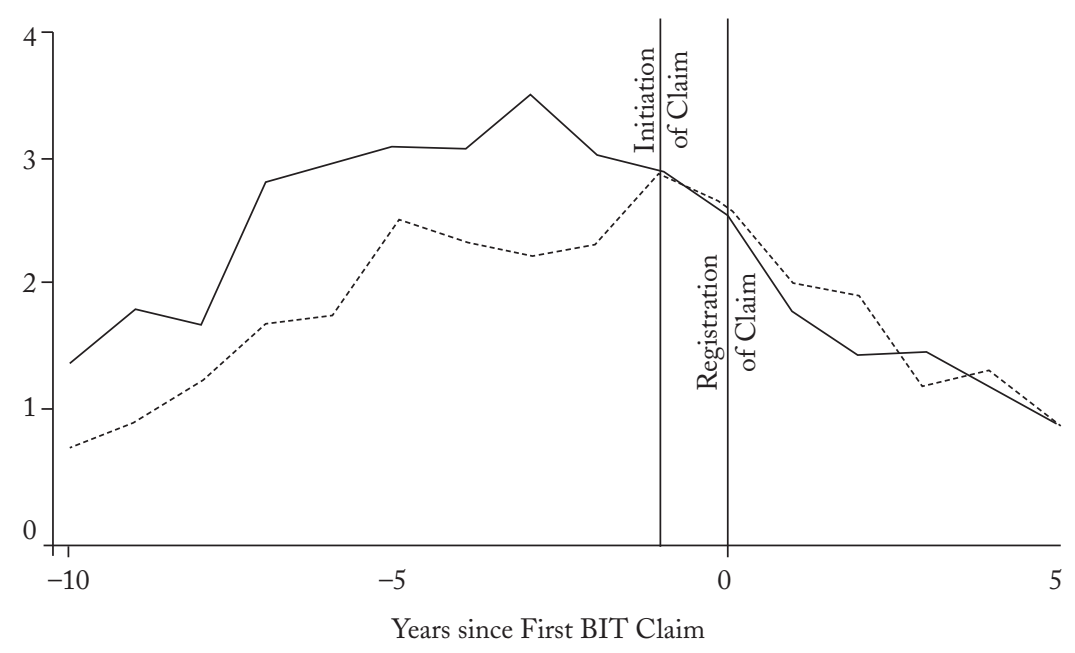

Av. Signing Rate

Av. Ratification Rate

FiguRE 2

BiT Participation about Time of First Claim

period. Apart from Western countries, this definition excludes countries such as South Korea, Singapore, and several Arab oil-exporting states. Although these countries have signed numerous treaties with Western countries, their role in BIT negotiations is arguably often that of capital exporters, particularly when negotiating with low-income countries. ${ }^{44}$

Based on the interview findings, our principal empirical hypothesis is that of bounded rationality, that is, that developing countries tended to strongly decrease their participation in BITs only in response to experiencing a BIT arbitration claim against themselves. We examine the statistical validity of this hypothesis by estimating the negative binomial fixed-effects model of Hausman, Hall, and Griliches, ${ }^{45}$ with dependent and independent variables as in equation 1.

Our parameter of interest in equation 1 is $\varphi$.

$$
f\left(\text { BITs }_{i t+1} \mid \text { BITClaim }_{i t}, X_{i t}\right)=g\left(\exp \left(\varphi \text { BITClaim }_{i t}+\alpha X_{i t}+\eta_{t}\right)\right)
$$

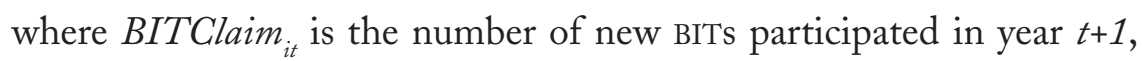

\footnotetext{
${ }^{44}$ Salacuse 1990.

${ }^{45}$ Hausman, Hall, and Griliches 1984.
} 
$B I T s_{i t+1}$ is a dummy variable which is zero in years before the first BIT claim was lodged against country $i$, and one otherwise,

$X_{i t}$ comprises FDI inflows, net GDI outflows, GDP, the investment risk index, and controls for previous BIT participation,

$\eta_{t}$ are year effects, and

$\varepsilon_{i t}$ are idiosyncratic errors.

In the subsequent subsections we discuss in detail each of the variables in equation 1 , as well as our choice of estimator for the regression equation. Before proceeding with this, however, it is worth noting that the structure of our regression approach differs from that in the leading models of BIT participation. ${ }^{46}$ Our panel data set is intentionally constructed of country-year observations, whereas the earlier articles have used country-pair (that is, dyad-year) data. The dyad-year approach was necessary for comprehensive models of BIT participation that sought to test hypotheses about the impact on BIT formation of the relationship between treaty partners (for example, income differences, colonial relations). In contrast, our hypotheses of interest are country level. For this the dyad-year structure is not necessary. Furthermore, in the interest of space, we intentionally avoided the dyadyear models in order to keep our analysis focused on our hypotheses of interest and avoid discussion of the many other variables included in the dyadic models. However, as a robustness check and to provide comparison with existing literature, we show that our results also hold using the dyadic data and models of Elkins, Guzman, and Simmons (EGS) and Jandhyala, Henisz, and Mansfield (JHM). ${ }^{47}$ The fact that our findings remain consistent across three different data sets and econometric approaches speaks strongly to the robustness of our result. As we discuss in Section IV, using the frameworks of EGS and JHM also allows us to demonstrate an auxiliary result that strengthens our conclusions regarding bounded rationality.

\section{DePENDENT VARIABLE(s)}

Based on UNCTAD's country lists of BITs, our main dependent variable counts the number of BITs signed by a developing country in a given year. This is a standard measure for quantitative studies on the diffusion of BITs. ${ }^{48}$ It is based on the simplified, yet reasonable assumption that BITs are comparable in their substantive and procedural

\footnotetext{
${ }^{46}$ EGs 2006; Jandhyala, Henisz, and Mansfield 2011.

${ }^{47}$ The EGS robustness check is presented in Section IV. The same exercise is repeated using the data and econometric approach of JHM in the appendix.

${ }^{48}$ E.g., EGs 2006.
} 
provisions. ${ }^{49}$ One aspect where BITs do systematically and meaningfully vary, however, is in their provisions for dispute settlement, since it was not until the late 1980s that BITs began, as a general rule, to give investors access to investor-state arbitration without first having to exhaust local remedies. ${ }^{50}$ Although occasionally overlooked by international relations contributions, ${ }^{51}$ this difference is crucial, as investment treaties would be largely irrelevant for foreign investors without their effective and comprehensive consent to investor-state arbitration. ${ }^{52}$ We therefore restrict our sample to the period when the vast majority of BITs included a binding consent to investor-state arbitration, namely, from 1990 onward.

To check the robustness of our results, we also use two alternative measures of BIT participation. The first is the number of BITs that came into force in a given year (hereafter referred to as "ratified BITs"). The advantage of this measure is that it captures the propensity to enter into BITs that are actually legally binding; the disadvantage is that idiosyncratic ratification processes introduce measurement error. ${ }^{53}$

Our final measure of BIT participation is the number of BITs signed by a developing country in a given year that came into force (that is, were "ratified") within three years of being signed. Though novel, this measure combines the key strengths of each of the measures of participation commonly used in the literature. Like "ratified" BITs, this alternative measure of participation has the advantage of not counting BITs that countries sign without the intention of making them legally binding. As with "signed BITs," this measure avoids the measurement error introduced in the "ratified BITs" measure by idiosyncrasies in the (often lengthy) ratification process in each country. We chose three years as our cutoff, as more than four-fifths of BITs that have entered into force did so within three years of signature. ${ }^{54}$

\footnotetext{
${ }^{49}$ The content of BITs is largely similar, and although some recent studies have coded BITs' content (Yackee 2008; Allee and Peinhardt 2010), they remain too restrictive or cover too few treaties to be useful for our purposes. Also, even when differences exist, they are often leveled out by the MFN provision, which, combined with BITs' often broad definition of investors and investments, provide ample opportunities for "treaty shopping," which makes differences between BITs even less relevant in practice; Legum 2006; Schill 2009.

${ }^{50}$ Yackee 2008.

${ }^{51}$ E.g., Egs 2006; Jandhyala, Henisz, and Mansfield 2011.

${ }^{52}$ Wälde 2005. It is unclear from arbitral decisions to what extent investors can use MFN clauses to "import" more favorable dispute settlement provisions from other treaties (Hsu 2006). This makes the specific wording of arbitration provisions particularly important to assess the protection granted in individual BITs.

${ }^{53}$ The vast majority of BITs come into force after the contracting parties have notified each other that their domestic requirements are met. Such requirements vary across countries, but in practice this often means that both national parliaments have to ratify the BIT before it enters into force.

${ }^{54}$ UNCTAD 2006.
} 


\section{Main EXPlanatory VARIABLE}

Our explanatory variable of interest is a dummy variable that takes the value of one beginning the year a country was subject to its first BIT claim-defined as the year the claim was registered by the arbitral tribunal-and zero otherwise. ${ }^{55}$ While our base regression includes only the relatively simple "first claim" dummy variable, we also considered more refined measures of BIT claim experience, including the number of claims a country has faced, the size of the award sought by the investor, BIT-related claims brought under other legal jurisdiction, and whether the host "lost" the case. None of these refinements affect the base result, a finding that lends further support to our bounded rationality hypothesis. ${ }^{56}$

\section{Other Control Variables}

A key component of our identification strategy is the inclusion of a full set of year dummies to control for global shocks shared by all countries, including business cycles, changing global norms toward foreign capital (for example, the rise and fall of the Washington consensus), the global number of BITs, and the global number of BIT claims. Controlling for global BIT claims in this way means that the effects we observe are additional to any effect of claims against other countries. Thus, if countries treated claims against other countries as being as informative as claims against themselves, or if they were merely responding to a secular shift in BIT participation norms as suggested by JHM, we would expect to find zero effect from our variable of interest (own BIT claims).

Our base model also controls for a country's FDI inflows and outflows, as well as for its market size/level of economic development proxied by GDP. We control for these macroeconomic flows to account

\footnotetext{
${ }^{55}$ The variable may have a small amount of measurement error, as the secrecy of some disputes adjudicated under non-ICSID rules means we cannot be entirely sure when a country was hit by a BIT claim for the first time. However, the vast majority of investment treaty awards have found their way to the public domain. Furthermore, even if we are missing the first claims for a few countries, it would make our results more conservative, that is, bias against finding an effect of the first treaty claim. Similarly, while the year a country was subject to its first BIT claim is not necessarily the year it was first threatened with a claim, this also makes it more difficult to find an effect from first BIT claims and therefore biases against evidence for bounded rational learning. Finally, a claim indicates the relevance of BITs for investment protection and is therefore likely to lead to increased lobbying for BIT formation by foreign investors not covered by treaty protections; so this too will make it less likely to find an effect of the first claim.

${ }^{56}$ The result regarding number of claims is in Table 5; those for size and jurisdiction are in Table A3 in the appendix. The result for "losing" a claim is available upon request from the authors but is not presented here, as this variable is subject to significant measurement error due to out-of-court settlements and the many pending cases, as well as methodological concerns in construing a quantitative measure for when countries have actually "lost" a claim.
} 
for the fact that the level of foreign investor interest in the host may affect the number of BITs it can choose to sign. ${ }^{57}$ We further control for investment risks (using the Political Risk Services Group Index), as a government with protectionist urges regarding FDI may be simultaneously at higher risk for BIT claims and less inclined to sign BITs. All of these explanatory variables are lagged one year to avoid simultaneity.

Finally we include a range of indicators to control for saturation, that is, the fact that a slowdown in a country's BIT participation can be a function of the size of its existing BIT network. Since a more extensive BIT network will also increase the probability of a claim (ceteris paribus), omitting previous participation would likely lead us to overestimate the downward effects of claims. We therefore control for a cubic polynomial function of the cumulative number of BITs participated in (measured by signing or ratification according to the dependent variable in the regression). Additionally, since claims only arise from ratified BITs, we control for the cumulative number of BITs ratified with four- and ten-year lags in all estimations.

Summary statistics and sources for all raw and constructed variables used in our analysis are provided in Table A1 in the appendix. Missing data for some series means that our base regression uses around 1600 of the potential 2740 observations.

\section{Additional Robustness Tests}

Apart from a robustness check of the choice of estimator and specification of both the dependent and the main explanatory variable, we also checked the robustness of our findings to adding or removing other control variables. For instance, we removed - one at a time-any of the controls in our base regression that might potentially be endogenous or cause other forms of bias. We also checked the robustness of our results to the inclusion of two additional controls. First, using the World Bank's database on political institutions, ${ }^{58}$ we captured possible partisan biases by including a dummy variable indicating whether a country's executive and/or majority party was left wing. Second, we checked for whether a country's BITs have been used to adjudicate claims against other countries: for while only few developing country investors have filed BIT claims, the rising stocks of investment from developing countries mean they increasingly have an interest not only

\footnotetext{
${ }^{57}$ For example, controlling for FDI flows means that our results will not be biased by any decreased investor interest in the host, which the work of Allee and Peinhardt 2011 suggests may be caused by BIT claims.

${ }^{58}$ Beck et al. 2001.
} 
in attracting investment from the West but also in protecting their own investors abroad. We do not present these results here, however, as neither control had any appreciable explanatory power or impact on other coefficients. ${ }^{59}$

\section{Augmented Models and Ancillary Questions}

As many countries experienced their first investment treaty claim around the same time, we include specifications that control for crossborder learning effects by including dummy variables for whether a country within the same region has been hit. This is a much simpler approach than that used by EGS, for instance, who include complex (and highly data dependent) diffusion measures based on ambitious assumptions of highly advanced BIT strategies. ${ }^{60}$ Based on our interviews, we are less optimistic about the sophistication of developing country strategies in the international investment regime and therefore limit learning effects to countries within the same region. Note again, however, that any observed impact of this variable is over and above the impact of the global number of claims (that is, also claims far away).

Finally, we studied specifications that distinguish between BIT partners. For although BITs are largely comparable in their legal content, hundreds of BITs have been signed between countries that exchange next to zero investment flows. While legally binding, and at times relevant through the MFN provision, these treaties are rarely important in practice. Similarly, since the vast majority of claims (still) involve Western investors suing developing country governments, we distinguish between North-South and South-South BITs. We also use an alternative classification, according to which only South-South treaties that do not have a major developing country capital exporter as one of the contracting parties are considered "frivolous" BITs. ${ }^{61}$

\section{REsults}

Table 3 reports coefficients from our base specification. The dependent variables from left to right are, respectively, the annual number of BITs signed, ratified, and signed and then ratified within three years. In all three columns the effect of having at least one BIT claim is negative, and we are able to reject the null of positive or no effect at the

\footnotetext{
${ }^{59}$ Results available from the authors upon request.

${ }^{60}$ EGS 2006.

${ }^{61}$ This measure was constructed by taking the country's outward FDI stock as a share of the total developing country sample outward FDI stock and calculated the maximum, average, and median shares. Top ten from each were then considered large developing country capital exporters.
} 
TABLE 3

Strong Negative Effect of First Bit Claim on Participation in BITs by Developing Countries ${ }^{a}$

\begin{tabular}{lccc}
\hline \hline & Signing & Ratifying & Sign E Ratify \\
\hline L.BIT Claim & $-0.423^{* * *}$ & $-0.187^{*}$ & $-0.463^{* * *}$ \\
& $(0.107)$ & $(0.112)$ & $(0.144)$ \\
L.Inward FDI & -0.016 & 0.009 & $-0.030^{* *}$ \\
& $(0.011)$ & $(0.011)$ & $(0.014)$ \\
L.Outward FDI & -0.011 & -0.006 & 0.016 \\
& $(0.014)$ & $(0.013)$ & $(0.020)$ \\
L.GDP & $0.001^{* *}$ & 0.001 & $0.002^{* * *}$ \\
& $(0.001)$ & $(0.001)$ & $(0.001)$ \\
L.Invest.Protect. & $0.071^{* * *}$ & $0.092^{* * *}$ & $0.067^{* *}$ \\
& $(0.022)$ & $(0.025)$ & $(0.028)$ \\
Constant & $2.260^{* * *}$ & $2.467^{* * *}$ & $-2.021^{* *}$ \\
& $(0.494)$ & $(0.555)$ & $(0.885)$ \\
Observations & 1604 & 1524 & 1448 \\
\hline
\end{tabular}

${ }^{*} p<0.10,{ }^{* *} p<0.05,{ }^{* * *} p<0.01$

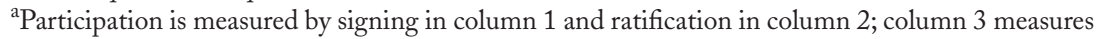
BITs signed in that year which where ratified within three years. Sample size varies across columns as countries for which dep. var. is always zero are dropped. Table reports coefficients from negative binomial, fixed-effect estimation; standard errors in parentheses. Year dummies and cubic function of lagged total BIT participation as well as four- and ten-year lags of ratification also included but coefficients not reported. All other controls are lagged one year.

5 percent significance level or better. ${ }^{62}$ The experience of a BIT claim reduces signing by about 35 percent and ratification by somewhat less, by about 17 percent. ${ }^{63}$ This provides strong support for our hypothesis that (1) when a country is subject to at least one BIT claim, it reduces its participation in BITs considerably and that (2) this effect is over and above any effect from observing claims against other countries. While one could think of a number of reasons for this statistical result, the underlying causal process was made clear from the qualitative evidence above: although in some cases developing countries may have learned about other countries' experiences-either directly or via intermediaries - many failed to consider the risks of BITs until hit by a claim themselves. ${ }^{64}$

${ }^{62}$ The one-sided nature of the t-test for our null allows us to reject the null at 5 percent level of significance even in the regression with ratification as the dependent variable.

${ }^{63}$ E.g., $1-\exp (-0.423)=0.34$. Note that, as expected, the results are weaker when "ratification" is the dependent variable due to the idiosyncratic differences.

${ }^{64}$ Similarly, Haftel and Thompson 2012 find that while countries' own experiences with disputes increase the chances that they will renegotiate BITs, experiences of other countries have no such effect. 
TABLE 4

Timing of Significant Reduction in Participation Coincides with First BIT CLAIM ${ }^{a}$

\begin{tabular}{|c|c|c|c|c|c|}
\hline & (1) & (2) & (3) & (4) & (5) \\
\hline F2.BIT Claim & $\begin{array}{c}-0.134 \\
(0.098)\end{array}$ & & & & \\
\hline F.BIT Claim & & $\begin{array}{c}-0.158 \\
(0.010)\end{array}$ & & & \\
\hline BIT Claim & & & $\begin{array}{c}-0.325^{\text {**** }} \\
(0.103)\end{array}$ & & \\
\hline L.BIT Claim & & & & $\begin{array}{c}-0.423^{* * * *} \\
(0.107)\end{array}$ & \\
\hline L2.BIT Claim & & & & & $\begin{array}{c}-0.302^{\text {**** }} \\
(0.110)\end{array}$ \\
\hline L.Inward FDI & $\begin{array}{l}-0.028^{* * * *} \\
(0.011)\end{array}$ & $\begin{array}{r}-0.018^{*} \\
(0.011)\end{array}$ & $\begin{array}{c}-0.017 \\
(0.011)\end{array}$ & $\begin{array}{c}-0.016 \\
(0.011)\end{array}$ & $\begin{array}{c}-0.017 \\
(0.011)\end{array}$ \\
\hline L.Outward FDI & $\begin{array}{c}0.000 \\
(0.016)\end{array}$ & $\begin{array}{c}-0.012 \\
(0.015)\end{array}$ & $\begin{array}{c}-0.012 \\
(0.014)\end{array}$ & $\begin{array}{c}-0.011 \\
(0.014)\end{array}$ & $\begin{array}{c}-0.011 \\
(0.014)\end{array}$ \\
\hline L.GDP & $\begin{array}{l}0.002^{* * * *} \\
(0.001)\end{array}$ & $\begin{array}{l}0.001^{\text {**** }} \\
(0.001)\end{array}$ & $\begin{array}{c}0.001^{* *} \\
(0.001)\end{array}$ & $\begin{array}{c}0.001^{* *} \\
(0.001)\end{array}$ & $\begin{array}{c}0.001^{* * *} \\
(0.001)\end{array}$ \\
\hline L.Invest.Protect. & $\begin{array}{l}0.064^{* * * *} \\
(0.022)\end{array}$ & $\begin{array}{c}0.072^{* * * *} \\
(0.022)\end{array}$ & $\begin{array}{l}0.069^{* * * *} \\
(0.022)\end{array}$ & $\begin{array}{l}0.071^{* * * *} \\
(0.022)\end{array}$ & $\begin{array}{l}0.073^{\text {**** }} \\
(0.022)\end{array}$ \\
\hline Constant & $\begin{array}{l}2.500^{\text {***** }} \\
(0.520)\end{array}$ & $\begin{array}{l}2.078^{* * * *} \\
(0.493)\end{array}$ & $\begin{array}{l}2.173^{\text {**** }} \\
(0.492)\end{array}$ & $\begin{array}{l}2.260^{\text {**** }} \\
(0.494)\end{array}$ & $\begin{array}{l}2.205^{\text {**** }} \\
(0.497)\end{array}$ \\
\hline Observations & 1518 & 1604 & 1604 & 1604 & 1604 \\
\hline
\end{tabular}

${ }^{*} p<0.10,{ }^{* *} p<0.05,{ }^{* * * *} p<0.01$

${ }^{\text {a }}$ Dependent variable is the annual number of BITs signed. Table reports coefficients from negative binomial, fixed-effect estimation; standard errors in parentheses. Year dummies and cubic function of lagged total BIT participation as well as lags of ratification also included but coefficients not reported. All other controls are lagged one year.

Although our results are backed up by interviews with government officials themselves, we may still be concerned that the statistical correlations are driven by a tendency for first claims to occur after BIT participation has already started to decline. The graphical "event study" in Figure 2 provides suggestive evidence that, to the extent participation was already in decline, the first claim exaggerated this trend. Table 4 provides regression-based evidence to further support this and thus allay the concern that our results are driven by spurious correlation with some underlying trend toward decreased participation. In the interests of space, the results are presented only for signing as the dependent variable. Signing was chosen over "signed and ratified," since the two measures have very similar results but the former is more consistent with the existing literature on BIT participation. Columns 1-5 in Table 
TABLE 5

First Claim against a Country Matters but Cumulative Number of Claims Does Not, while Cumulative Claims in the Region Matter and First Claim Does Not ${ }^{\mathrm{a}}$

\begin{tabular}{lcccc}
\hline \hline & $(1)$ & $(2)$ & $(3)$ & $(4)$ \\
\hline L.Cum. BIT Claims & -0.018 & -0.003 & -0.003 & 0.010 \\
& $(0.019)$ & $(0.016)$ & $(0.016)$ & $(0.016)$ \\
L.BIT Claim & & $-0.419^{* * *}$ & $-0.416^{* * * *}$ & $-0.393^{* * *}$ \\
& & $(0.110)$ & $(0.111)$ & $(0.110)$ \\
L.Region BIT Claim & & -0.015 & 0.010 \\
& & & $(0.098)$ & $(0.097)$ \\
L.Region cum.BIT Claims & & & $-0.011^{* * *}$ \\
& & & & $(0.004)$ \\
L.Inward FDI & $-0.018^{*}$ & -0.016 & -0.016 & -0.017 \\
& $(0.011)$ & $(0.011)$ & $(0.011)$ & $(0.011)$ \\
L.Outward FDI & -0.012 & -0.011 & -0.011 & -0.011 \\
& $(0.015)$ & $(0.014)$ & $(0.014)$ & $(0.014)$ \\
L.GDP & $0.001^{* * * *}$ & $0.001^{* *}$ & $0.001^{* *}$ & $0.001^{* *}$ \\
& $(0.001)$ & $(0.001)$ & $(0.001)$ & $(0.001)$ \\
L.Invest.Protect. & $0.071^{* * *}$ & $0.071^{* * *}$ & $0.071^{* * *}$ & $0.073^{* * *}$ \\
Constant & $(0.022)$ & $(0.022)$ & $(0.022)$ & $(0.022)$ \\
& $2.036^{* * *}$ & $2.253^{* * *}$ & $2.272^{* * *}$ & $2.808^{* * *}$ \\
Observations & $(0.497)$ & $(0.495)$ & $(0.509)$ & $(0.541)$ \\
\hline
\end{tabular}

${ }^{*} p<0.10,{ }^{* *} p<0.05, * * * p<0.01$

${ }^{a}$ Dependent variable is the annual number of BITs signed. Table reports coefficients from negative binomial, fixed-effect estimation; standard errors in parentheses. Year dummies and cubic function of lagged total BIT participation as well as lags of ratification also included but coefficients not reported. All other controls are lagged one year.

4 control respectively for two years prior to the registration of the first BIT claim through two years after the BIT claim is lodged. If our BIT claim dummy were picking up some spurious trend, we would expect all the coefficients on the different leads and lags of BIT claims to be similar. Instead we find that the coefficients in the year of the BIT claim and the two subsequent years are roughly twice as large are those in the two years prior.

Furthermore, the coefficients on BIT claim one and two years prior (columns 1 and 2) are not significant at the 10 percent level, while the coefficients in columns 3-5 are negative and significant at the 1 percent level. These results correspond well with Figure 2 and provide strong evidence that the structural break in participation behavior coincides with the registration of the first BIT claim. 
Being confident of the robustness of our primary result, we now consider ancillary questions. Table 5 examines the impact of increasing numbers of claims against a host and of claims against countries in the same region. In all specifications in Table 5 we see that the total number of BIT claims (Cum. BIT claims) is only very weakly negatively correlated with participation, suggesting that learning about the potential of BITs occurs primarily in response to the first BIT claim. This corresponds well with the predictions of bounded rationality, namely, that a single "vivid" event often has a considerably greater impact than would be expected by Bayesian frameworks. The latter would predict that each additional claim reveals further information about the risks BITs entail, yet this is not what we find.

Columns 3 and 4 of Table 4 examine the response to claims against other countries in the same region. Interestingly the pattern is reversed here: countries show little response to the first claim in the region but do seem to respond to the cumulative average number of claims per country in the region. This is not too surprising: claims against other countries in the region are likely to elicit significantly less of an emotional response for policymakers than claims against their own country. Thus our result suggests that, consistent with theories of bounded rationality, policy learning is more "rational" when the emotional content of the information is lower.

Finally, Table 6 addresses the question of whether participation in "serious" BITs responds in the same way as participation in more "frivolous," or "photo-opportunity," BITs. The perceived benefits of participation in BITs for countries can range from apparently minor ones such as "having something to do" when a foreign dignitary visits to encouraging much-needed high-technology investment. ${ }^{65}$

Similarly, the potential costs of BITs may appear negligible (for example, if there is almost no inflow of FDI ever likely from the partner country) or they may be substantial (for example, if there are substantial amounts of investment from the partner in high political-risk sectors). So if our results are driven purely by a slowdown in BITs, with few, if any, implications (except through the MFN clause), our analysis may have little relevance for the investment regime overall. Yet Table 6 shows that this is not the case. While participation in all types of BITs responds negatively to a claim, the impact is strongest for BITs with the largest potential economic implications.

${ }^{65}$ The latter is questionable. For recent studies, see Aisbett 2009; Yackee 2010; and Poulsen 2010. 
TABLE 6

Participation in BITs with Potentially Significant Economic Implications Is More Affected by Claims Than Participation in "Photo-OpPortunity" BITsa

\begin{tabular}{lcccc}
\hline \hline & $(1)$ & $(2)$ & $(3)$ & $(4)$ \\
& North-South & South-South & Serious & $\begin{array}{c}\text { Photo- } \\
\text { Ops. }\end{array}$ \\
& BITs & BITs & BITs & -0.198 \\
L.BIT Claim & $-0.373^{* *}$ & $-0.257^{* *}$ & $-0.421^{* * *}$ & $-130)$ \\
L.Inward FDI & $(0.170)$ & $(0.125)$ & $(0.150)$ & $(0.136)$ \\
& $-0.044^{* * *}$ & $-0.024^{*}$ & $-0.030^{* *}$ & $-0.025^{*}$ \\
L.Outward FDI & $(0.017)$ & $(0.013)$ & $(0.014)$ & $(0.014)$ \\
& $-0.067^{* *}$ & -0.018 & $-0.051^{* *}$ & -0.021 \\
L.GDP & $(0.026)$ & $(0.015)$ & $(0.022)$ & $(0.016)$ \\
& $0.003^{* * * *}$ & $0.003^{* * *}$ & $0.002^{* * *}$ & $0.003^{* * * *}$ \\
L.Invest.Protect. & $(0.001)$ & $(0.001)$ & $(0.001)$ & $(0.001)$ \\
& $0.093^{* * * *}$ & $0.063^{* *}$ & $0.059^{* *}$ & $0.086^{* * * *}$ \\
Constant & $(0.033)$ & $(0.025)$ & $(0.028)$ & $(0.029)$ \\
& $3.114^{* * *}$ & $3.186^{* * *}$ & $2.890^{* * *}$ & $2.974^{* * *}$ \\
Observations & $(0.778)$ & $(0.509)$ & $(0.664)$ & $(0.551)$ \\
\hline
\end{tabular}

$* p<0.10, * * 0<0.05, * * * 0<0.01$.

${ }^{\text {a }}$ Dependent variable is the annual number signed of the type of BITs described in the column heading. "Serious" BITs are either North-South BITs or South-South BITs, where at least one party is a major capital exporter. "Photo-Op" BITs are South-South BITs between countries that are not major capital exporters. Table reports coefficients from negative binomial, fixed-effect estimation; standard errors in parentheses. Year dummies and cubic function of lagged total BIT participation as well as lags of ratification also included but coefficients not reported. All other controls are lagged one year.

\section{Alternative Explanations Based on Full Rationality}

Our findings thus far have provided robust evidence of highly narcissistic learning about treaty claims - consistent with the bounded rationality framework. In this final section we consider the extent to which our findings might be explained using two leading alternative models, namely, full rationality with full information and full rationality with imperfect information.

\section{Full Rationality With Full Information}

If negotiators pursued BITs primarily in response to individual interests (for example, larger budgets, facilitating travel abroad), perhaps they actually did know about the implications of BITs, yet the political costs of pursuing them for selfish reasons simply became too high once the claims began. We find this explanation unlikely. First of all, it would 
have to rest on a major conspiracy, given that all stakeholders interviewed have stated independently of one other that most developing countries failed to fully consider the risks of BITs until they were hit by the first claim. Even some official reports and internal documents admit this. This is important, as a number of stakeholders have often had an individual interest in cautious BIT strategies. These include legal officers vetting the treaties, whose careers could be jeopardized if they had misinformed their principals about their international legal obligations; finance ministries, which would often have to "pay the bill" in the event of disputes; or regulatory agencies, whose autonomy would be constrained. However, all feedback from officials indicated that BITs have typically been completely nonpoliticized in national policymaking processes, and stakeholders rarely got involved in BIT policies until the first claim hit. This is difficult to explain using a public choice framework.

\section{Full RATIONALITY WITH IMPERFECT INFORMATION}

There is another potential explanation, however, that may intuitively carry more weight. If we acknowledge that some degree of learning from one's own experiences is indeed rational-even when faced with low-probability events - then bounded rationality and Bayesian learning models may in fact be observationally equivalent.

A rational stakeholder would know that the probability of a claim depends on a large number of factors, including the investment and governance profile of the country. She therefore knows that a claim against her own country or a similar (for example, a neighboring) country provides more information about the probability they will face future claims than a claim against a more "distant" country. Thus a rational but imperfectly informed stakeholder would react more strongly to claims close by - and even more so to claims at home - than to more distant claims. In this regard, then, the difference between the Bayesian and bounded rationality learning models remains one of degree. Taking this logic one step further, Meseguer argues that "bounded learning and rational learning yield the same results as soon as one drops the rational learning assumption that there are zero costs to gathering new information." ${ }^{66}$

In this respect, however, we agree with Conlisk, who points out that there is no inherent reason why information costs should be a more logical assumption than cognition costs a priori. ${ }^{67}$ Also, while we do

${ }^{66}$ Meseguer 2006, 1.

${ }^{67}$ Conlisk 1996. 
not disagree with Meseguer's conclusion of observational equivalence in the context of her specific case study, we find it unlikely that a rational learner would react so strongly to the first claim at home while completely ignoring the first claim in the region, as we found in the statistical analysis. We also find it unlikely that a rational learner would react strongly to the first claim against her country rather than learning progressively from the accumulation of subsequent claims. Moreover, unlike Meseguer, who relies almost exclusively on econometric evidence, we have presented interview feedback on the process with which developing countries have learned about BITs, which clearly indicates bounded rational learning. For, while it may not have necessarily violated standard expected utility theory if governments underestimated the risks of BITs, only bounded rationality can explain why they were ignored completely. ${ }^{68}$

Finally, even if this does not convince skeptics of the added value of a bounded rationality framework, the bilateral nature of our case study allows us in a last robustness test to provide a clear rational baseline, which other studies have had difficulties providing. Existing international relations literature on policy learning tends to focus on unilateral policy decisions involving only one country. ${ }^{69}$ Yet this provides only one dimension of "relevant" information, which in turn makes it difficult to distinguish bounded and fully rational learning. BITs, by contrast, are bilateral, which means that there are potentially two dimensions of relevance, or "distance," to a piece of information: one in relation to the "host" country and one in relation to the partner country. And concerning their sensitivity to this second dimension of distance, the fully and bounded rational learners will differ even more than on their sensitivity to the first. Analogously to the case of closeness for the host country, a fully rational policy learner will place more weight on cases brought by investors from the potential BIT partner than it will on other cases. This is rational since the probability that claims are brought by a certain country is likely to vary with the amount and type of outward investment of the country, the experience of home country lawyers in bringing BIT claims, and so on. In contrast, a bounded rational learner may ignore the readily available information about BIT claims brought by investors from the potential partner country. The availability heuristic will not apply in the same way as with claims against the host, since claims brought by the partner are not as "vivid." Thus, on the question

\footnotetext{
${ }^{68}$ See again, for example, Camerer and Kunreuther 1989.

${ }^{69}$ E.g., Weyland 2006; Meseguer 2009; Gilardi, Füglister, and Luyet 2009.
} 
of how BIT participation responds to claims brought by potential partner countries, bounded and full rational learning models are not observationally equivalent.

In order to test our competing hypotheses with regard to claims brought by the potential partner, we make use of the data sets and empirical methodologies of the two leading articles on BIT diffusion: Elkins, Guzman, and Simmons (EGS) and Jandhyala, Henisz, and Mansfield (JHM).$^{70}$ Both articles use country-dyad data sets and a survival analysis approach to examine the determinants of BIT formation between partners. Since the findings are so similar, and in the interests of space, we present and discuss the results for the EGS data set here (see Table 7) and those for the JHM data set in the appendix (see Table A4). Table 7 reports the estimated odds ratios for EGS's main explanatory variable of interest and for our explanatory variables of interest. ${ }^{71}$ In the first column we reproduce EGS's preferred regression and obtain exactly the same estimated odds ratio on their main variable (BITs among export product competitors) as reported in their article. ${ }^{72}$ The odds ratio is greater than one and statistically significant, which EGS interpret as evidence in support of their rational, competition-driven theory of BIT diffusion. In column 2, consistent with our main regressions, we restrict the sample period to post-1989- the period in which BITs actually had some legal "bite." We include this column to show that this change alone causes the odds ratio for EGs's export competition variable to no longer be statistically significantly different from one. ${ }^{73} \mathrm{We}$ are agnostic about this finding, however, as we are not disputing that developing countries have signed BITs primarily in an attempt to attract foreign investment (see the conclusion). Also, responding to behavior of "competitors" is potentially consistent with both fully rational and bounded rational learning models. ${ }^{74}$

In column 3 of Table 7 we add our "BIT claim" explanatory variable of interest, as well as an unrestricted quadratic in total BITs signed by

\footnotetext{
${ }^{70}$ Elkins, Guzman, and Simmons 2006; Jandhyala, Henisz, and Mansfield 2011.

${ }^{71}$ Other variables as per the footnote to Table 7 -including all variables that are in EGs, Table 2, model 2-are included in the regression, but results are not reported because of space constraints. Full results are available from the authors upon request. Note that our switch from reporting coefficients (as per earlier tables) to odds ratios here is in the interest of consistency with the way the results are reported in EGS.

${ }^{72}$ We report results based on model 2 in Table 2, EGs. We chose model 2 since it was empirically the strongest model favoring EGS's hypothesis of competition-led diffusion of BITs. Results based on the other models in Table 2 are qualitatively the same and are available from the authors upon request.

${ }^{73}$ An odds ratio of one suggests that the variable has no effect on the survival rate (that is, the probability of BIT formation at a given point in time).

${ }^{74}$ See Poulsen 2014.
} 
TABLE 7

Using the Data set of Elkins, Guzman, and Simmons 2006 (EGS) We

Show in a Bilateral Setting That Claims against Host Significantly

Reduce LiKelihood of BIT Formation while Claims Brought By Investors From Partner Have No EFFect ${ }^{a}$

\begin{tabular}{lcccc}
\hline \hline & $(1)$ & $(2)$ & $(3)$ & $(4)$ \\
\hline BITs among Export Product & $1.111^{\text {*now }}$ & 1.026 & 1.013 & 0.967 \\
Competitors & $(0.038)$ & $(0.039)$ & $(0.040)$ & $(0.040)$ \\
BIT Claim against (Host) & & & $0.786^{*}$ & $0.763^{\text {*** }}$ \\
& & & $(0.097)$ & $(0.095)$ \\
BIT Claim by (Source) & & & 1.017 \\
& & & & $(0.137)$ \\
Years Included & $1960-2000$ & $1990-2000$ & $1990-2000$ & $1990-2000$ \\
Observations & 208610 & 63461 & 61222 & 60083 \\
\hline
\end{tabular}

$* p<0.10, * * * 0.05, * * * * 0.01$

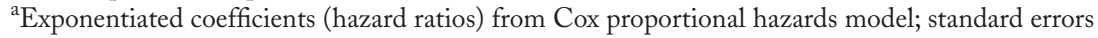
in parentheses. Column 1 of this table reproduces the results of model 2 of Table 2 in EGS 2006 with updated data set provided by EGS. "BITs among Export Product Competitors" is defined in EGS. Full set of controls included from EGS but not reported. Full set of results showing coefficients for all variables in the regression is available from the authors upon request. Column 2 of this table restricts EGs's regression to 1990-2000. Columns 3 and 4 add controls from our data for BIT participation (quadratic function) and claims for host and home/partner.

the host to control for previous BIT participation. As such, column 3 tests whether our main result is robust to the use of an alternative data set and an entirely different econometric approach. The odds ratio on our BIT claim variable is 0.786 and statistically significantly different from 1. Thus, our finding that a BIT claim decreases participation is robust to the use of a dyadic modeling approach.

In column 4 of Table 7 we add controls for a claim by investors from the potential partner country, as well as an unrestricted quadratic in previous partner-country BIT signing. These additions further decrease the odds ratio on our BIT claim variable, thereby strengthening our main claim. In contrast, the odds ratio for the variable indicating a BIT claim has been launched by investors from the potential partner country is greater than one, though this difference is not statistically significantly different from one. This is consistent with our prediction based on bounded rationality and again follows directly from the interview feedback: officials involved in investment treaty policy-making often ignored the readily available information about investment claims involving other countries until they themselves were hit by a claim. 


\section{CONCLUSION}

Developing countries have behaved "predictably irrationally" in the international investment regime. By following the availability heuristic, many have been excessively narcissistic when learning about the risks of BITs. Apart from alerting us to potential optimism bias among countries yet to experience their first BIT claim, these findings could have broader implications.

First, unlike several earlier international relations studies on bounded rationality, we were able to address the important critique of Meseguer, who argues that the large degree of observational equivalence between bounded rationality and Bayesian models renders the former an unimportant complication for international relations. ${ }^{75}$ Evidence against the accusation of observational equivalence is mounting in economics, ${ }^{76}$ and we found clear evidence against it in the international relations context as well.

Second, unlike economists and political scientists more generally, IPE analysts "have shown impressive resistance to the bounded rationality literature and its implications." 77 Ours is one of a few studies beginning to fill this gap, ${ }^{78}$ which begs the question of whether it is time to make bounded rationality a core area of interest for IPE. While of potential use for constructivist approaches, ${ }^{79}$ this could also be closely aligned with traditional rationalist literature studying how governments have pursued their (self-perceived) interests to the best of their ability. ${ }^{80}$ But unlike contributions based on comprehensive rationality, it would do so by taking cognitive constraints seriously.

For instance, a standard assumption in much rationalist IPE literature is that actors losing from a policy will lobby against it. ${ }^{81}$ But this did not happen for a long time in the investment regime because of information-processing biases among stakeholders. Might this finding hold in other areas as well, such as the regulation of "fat-tailed" risks in international financial markets? Similarly, we have focused on the role of the availability heuristic, but other heuristics-such as those of representativeness and anchoring-could also be important in explaining systematic patterns in economic diplomacy. ${ }^{82}$

${ }^{75}$ Meseguer 2006.

${ }^{76}$ Camerer 2004; Thaler 2005; Camerer, Loewenstein, and Rabin 2006.

${ }_{77}$ Odell 2002, 178. See also Elms 2008.

${ }^{78}$ Walter and Willett 2011; Hafner-Burton, Hughes, and Victor 2011; Hafner-Burton et al. 2012.

${ }^{79}$ See, for instance, Herrera's use of bounded rationality as a bridge to constructivism; Herrera 2007, chap. 2. See also Abdelal, Blyth, and Parsons 2010, 10-11.

${ }^{80}$ Weyland 2006, chap. 2. See, for example, Simon's notion of “intended rationality"; see Simon 1957.

${ }^{81}$ Lake 2009, 226.

${ }^{82}$ See, for example, Hafner-Burton et al. 2012. 
Parallel observations could be made about the settlement of international economic disputes. Behavioral approaches have become an established tradition in (particularly American) domestic legal studies, ${ }^{83}$ but they have yet to be applied to adjudication under international economic law. But why should WTO panels, investment treaty tribunals, or other international adjudicative bodies not be subject to the same biasing heuristics as domestic courts?

Our findings also have more specific implications for the study of the international investment regime. For while we have refrained from offering a general theory of BIT adoption in this article, our results imply that a bounded rationality framework could provide important hints as to why and how developing countries signed BITs in the first place. Although not necessarily seeking to refute the claim that many capital-importing countries have used modern BITs in an attempt to attract or retain capital, ${ }^{84}$ a bounded rationality approach would query just how careful government actors have been in the process. ${ }^{85}$ From this perspective, negotiators and stakeholders would not be as rigorous in assessing potential costs and benefits as assumed in optimizing frameworks, even if it would appear to be in their country's interest to be so.

One potentially important topic in this respect is whether systematic biases in decision making have varied with the extent of expertise in relevant government agencies. ${ }^{86}$ As expertise is essentially a response to cognition costs, it is difficult to incorporate into theory without reference to bounded rationality. ${ }^{87}$ And while experts are also prone to biased judgments, their prior knowledge reduces the biasing effects of heuristics; 88 this would mean that expertise is a potentially important intervening factor for understanding the scope conditions of a bounded rationality framework. ${ }^{89}$ So perhaps developing country governments have been more prone to biased processing of information about the implications of BITs than developed country counterparts with higher levels of administrative capacity. This goes also for the content - or design —of BITs; an issue we have left largely unexplored in this article.

\footnotetext{
${ }^{83}$ Sunstein 2000.

${ }^{84}$ Guzman 1998; Egs 2006; Bubb and Rose-Ackeman 2007; Montt 2009; Pinto, Pinto, and StierMoses 2011; Swenson 2009.

${ }^{85} \mathrm{On}$ the role of bounded rationality in institutional choice, see, generally, Weyland 2006. See also Jupille, Mattli, and Snidal forthcoming.

${ }^{86}$ On the lack of expertise among officials dealing with investment treaties in developing countries, see, for example, UNCTAD 2008; Poulsen 2014.

${ }^{87}$ Conlisk 1996.

${ }^{88}$ Neale and Bazerman 1991, 96.

${ }^{89}$ Weyland 2006, 60; Hafner-Burton, Hughes, and Victor 2011.
} 
Other extensions of our findings could follow from the fact that arbitration claims have made stakeholders better realize their own interests, and thus become increasingly involved in the process of adopting BITs. Partly as a result, governments have been less keen on signing the treaties and particularly hesitant about "serious"-and thus potentially costly - BITs with capital-exporting states. This increased politicization of BITs touches on a fundamental question in political science, namely, whether more participants in the policy-making process reduce the aggregate impact of individual biases? ${ }^{90}$ If they do, then bounded rationality insights could be less relevant for the political economy of BITs today than in the past, when only few officials were involved with the treaties. Yet there is no inherent reason to think that cognitive constraints that are systematic would cancel out in the aggregate. ${ }^{91}$ And even if they do, the high turnover in many developing country bureaucracies $^{92}$ may make the risks of BITs gradually less "vivid" for stakeholders without personal experience of past claims and thus potentially "depoliticize" the BIT adoption process once again.

Whether complementing standard IPE models, or as stand-alone explanatory frameworks, these are important questions arising from insights on bounded rationality that future studies might consider.

Appendix: Statistics, Econometrics, and Robustness Tests

TABLE A1

SuMMARY STATISTICS ${ }^{\text {a }}$

\begin{tabular}{|c|c|c|c|c|c|c|c|}
\hline Variable & Description/Measure & Mean & $S D$ & Min & $\operatorname{Max}$ & $N$ & Source \\
\hline BIT Claim & $\begin{array}{l}1 \text { if country has been } \\
\text { subject to a BIT } \\
\text { claim, } 0 \text { otherwise }\end{array}$ & 0.19 & 0.39 & 0 & 1 & 2740 & (I) \\
\hline $\begin{array}{l}\text { Cumulative } \\
\text { BIT Claims }\end{array}$ & $\begin{array}{l}\text { cumulative BIT } \\
\text { claims }\end{array}$ & 0.57 & 2.57 & 0 & 51 & 2740 & (I) \\
\hline Signed & annual BITs signed & 1.23 & 2.03 & 0 & 17 & 2740 & (II) \\
\hline $\begin{array}{l}\text { Cumulative } \\
\text { Signed }\end{array}$ & $\begin{array}{l}\text { cumulative BITs } \\
\text { signed }\end{array}$ & 16.16 & 18.89 & 0 & 124 & 2740 & (II) \\
\hline Ratified & $\begin{array}{l}\text { annual BITs coming } \\
\text { into force }\end{array}$ & 0.90 & 1.74 & 0 & 15 & 2740 & (II) \\
\hline $\begin{array}{c}\text { Cumulative } \\
\text { Ratified }\end{array}$ & $\begin{array}{l}\text { cumulative BITs } \\
\text { coming into force }\end{array}$ & 11.18 & 15.06 & 0 & 97 & 2740 & (II) \\
\hline
\end{tabular}


TABLE A1 cont.

\begin{tabular}{|c|c|c|c|c|c|c|c|}
\hline Variable & Description/Measure & Mean & $S D$ & Min & $\operatorname{Max}$ & $N$ & Source \\
\hline $\begin{array}{l}\text { Signed and } \\
\text { Ratified }\end{array}$ & $\begin{array}{l}\text { annual BITs signed } \\
\text { that came into } \\
\text { force within three } \\
\text { years }\end{array}$ & 0.73 & 1.55 & 0 & 15 & 2740 & (II) \\
\hline $\begin{array}{l}\text { Cumulative } \\
\text { Signed and } \\
\text { Ratified }\end{array}$ & $\begin{array}{l}\text { cumulative BITs } \\
\text { signed that came } \\
\text { into force within } \\
\text { three years }\end{array}$ & 8.63 & 11.32 & 0 & 85 & 2740 & (II) \\
\hline FDI Inflows & $\begin{array}{l}\text { net inflows, BOP, bn. } \\
\text { current USD }\end{array}$ & 1.64 & 6.90 & -4.75 & 148 & 2471 & (III) \\
\hline FDI Outflows & $\begin{array}{l}\text { net outflows, BOP, bn. } \\
\text { current USD }\end{array}$ & 0.44 & 3.21 & -3.51 & 67.68 & 2101 & (III) \\
\hline GDP & bn. current USD & 56.93 & 197.21 & 0.08 & 4330 & 2494 & (III) \\
\hline $\begin{array}{l}\text { Investor } \\
\text { Protection }\end{array}$ & $\begin{array}{l}\text { investment risk profile } \\
\text { index from } 0 \text { (very } \\
\text { high risk) to } 12 \\
\text { (very low risk) }\end{array}$ & 6.91 & 2.34 & 0 & 12 & 1949 & $(\mathrm{IV})$ \\
\hline $\begin{array}{l}\text { Regional BIT } \\
\text { Claim }\end{array}$ & $\begin{array}{l}1 \text { if a country in same } \\
\text { region has been } \\
\text { subject to a BIT } \\
\text { claim, } 0 \text { otherwise }\end{array}$ & 0.73 & 0.45 & 0 & 1 & 2740 & (I) \\
\hline $\begin{array}{l}\text { Cumulative } \\
\text { Regional } \\
\text { BIT claims }\end{array}$ & $\begin{array}{l}\text { cumulative BIT } \\
\text { claims in region }\end{array}$ & 9.27 & 16.53 & 0 & 91 & 2740 & $\begin{array}{l}\text { (I) \& } \\
(\mathrm{V})\end{array}$ \\
\hline $\begin{array}{l}\text { North-South } \\
\text { BITs Signed }\end{array}$ & $\begin{array}{l}\text { annual BITs signed } \\
\text { with developed } \\
\text { countries }\end{array}$ & 0.47 & 0.96 & 0 & 8 & 2740 & (II) \\
\hline $\begin{array}{l}\text { South-South } \\
\text { BITs Signed }\end{array}$ & $\begin{array}{l}\text { annual BITs signed } \\
\text { with developing } \\
\text { countries }\end{array}$ & 0.76 & 1.48 & 0 & 15 & 2740 & (II) \\
\hline $\begin{array}{l}\text { "Serious" BITs } \\
\text { Signed }\end{array}$ & $\begin{array}{l}\text { annual BITs signed } \\
\text { with developed } \\
\text { countries or } \\
\text { developing } \\
\text { countries with } \\
\text { large outward } \\
\text { capital stocks }\end{array}$ & 0.62 & 1.16 & 0 & 8 & 2740 & $\begin{array}{l}\text { (II) \& } \\
\text { (III) }\end{array}$ \\
\hline $\begin{array}{l}\text { "Photo-Op" } \\
\text { BITs Signed }\end{array}$ & $\begin{array}{l}\text { annual BITs signed } \\
\text { with developing } \\
\text { countries with } \\
\text { small outward } \\
\text { capital stocks }\end{array}$ & 0.60 & 1.29 & 0 & 15 & 2740 & $\begin{array}{l}\text { (II) \& } \\
\text { (III) }\end{array}$ \\
\hline
\end{tabular}

SourCEs: (I) unctad.org/iia-dbcases, worldbank.org/ICSID, ita.law.uvic.ca, and iareporter.com; (II) UNCTAD; (III) IMF IFS; (IV) PRS Group; (V) UN Millennium Development Goals Regional Groupings.

${ }^{\text {aS }}$ Sample covers 137 developing and transition economies from 1990 to 2009. 


\section{Choice of Estimator}

Since our dependent variable is a count variable, an estimator based on a gamma distribution is likely most appropriate. While acknowledging that there may be some resulting lack of efficiency compared to a simple poisson model, we have opted for a high degree of flexibility and estimate the fixed-effect negative binomial model of Hausman, Hall, and Griliches. ${ }^{93}$ Furthermore, lack of efficiency is not a major concern for us, as our coefficients of interest are generally significantly different from zero at the 1 percent level.

Fixed-effect estimators are the workhorse of cross-country panel applications because they significantly reduce the influence of omitted time-invariant country characteristics. In our case, relevant characteristics include factors such as region, legal tradition, geographical size, and colonial history. Yet using a full fixed-effect model for our purposes may cause bias, since the inclusion of lagged cumulative participation is akin to including a lagged dependent variable. ${ }^{94}$ Thus our base specification is something of a compromise, allowing for countryspecific dispersion in a negative binomial specification (thus allowing country-specific intercepts), but not being a pure fixed-effect model. ${ }^{95}$ In robustness checks we compare our results to those obtained in both a fixed-effect poisson model and a negative binomial model without country-specific dispersion. The results in Table A2 indicate that our choice of estimator does not qualitatively affect our findings.

Table A2 shows the robustness of the finding to the choice of estimator from within the set of count-data models that could potentially be used in the application. The strong negative impact of a BIT claim is detected by all the estimators. From left to right the estimators are a standard poisson, fixed-effect poisson, negative binomial (constant dispersion), Hausman, Hall, and Grilichies's "fixed effects" estimator (our base estimator), ${ }^{96}$ and a negative binomial model including countrydummies. ${ }^{97}$

\footnotetext{
${ }^{93}$ Hausman, Hall, and Griliches 1984.

${ }^{94}$ For a discussion, see Arellano and Honoré 2001.

${ }^{95}$ Allison and Waterman 2002.

${ }^{96}$ Hausman, Hall, and Grilichies 1984.

${ }^{97}$ The later is suggested by Allison and Waterman 2002.
} 


\section{TABLE A2}

Strong Negative Effect of First Claim on Participation Is Robust to Choice of Count-Data Estimator and Treatment of Country Effects ${ }^{a}$

\begin{tabular}{lccccc}
\hline \hline & $(1)$ & $(2)$ & $(3)$ & $(4)$ & $(5)$ \\
& Poisson & FE-Poisson & NegBin. & Base & NegBin-FE \\
\hline L.BIT Claim & $-0.417^{* * *}$ & $-0.343^{* * *}$ & $-0.468^{* * *}$ & $-0.423^{* * *}$ & $-0.379^{* * *}$ \\
& $(0.101)$ & $(0.089)$ & $(0.117)$ & $(0.107)$ & $(0.139)$ \\
L.Inward FDI & $-0.031^{* * *}$ & $-0.031^{* * *}$ & $-0.034^{* * *}$ & -0.016 & $-0.028^{* *}$ \\
& $(0.007)$ & $(0.008)$ & $(0.009)$ & $(0.011)$ & $(0.012)$ \\
L.Outward FDI & -0.021 & -0.015 & -0.004 & -0.011 & -0.010 \\
& $(0.025)$ & $(0.011)$ & $(0.017)$ & $(0.014)$ & $(0.014)$ \\
L.GDP & $0.002^{* * *}$ & $0.002^{* * *}$ & $0.002^{* * *}$ & $0.001^{* *}$ & $0.002^{* * *}$ \\
& $(0.000)$ & $(0.000)$ & $(0.000)$ & $(0.001)$ & $(0.001)$ \\
L.Invest.Protect & $0.051^{*}$ & $0.067^{* * *}$ & $0.077^{* * *}$ & $0.071^{* * *}$ & $0.088^{* * *}$ \\
& $(0.027)$ & $(0.018)$ & $(0.026)$ & $(0.022)$ & $(0.029)$ \\
Constant & $-1.972^{* * *}$ & & $-2.166^{* * *}$ & $2.260^{* * *}$ & -0.774 \\
& $(0.293)$ & & $(0.304)$ & $(0.494)$ & $(0.480)$ \\
lnalpha & & & $-0.482^{* * *}$ & & $-1.407^{* * * *}$ \\
& & & $(0.123)$ & & $(0.198)$ \\
Observations & 1632 & 1604 & 1632 & 1604 & 1632 \\
\hline
\end{tabular}

${ }^{*} p<0.10,{ }^{* * *} p<0.05,{ }^{* * * * k} p<0.01$

${ }^{\text {a }}$ Dependent variable is the annual number of BITs signed. See text for description of estimators. Coefficients and standard errors reported. Standard errors in columns 1, 3, and 5 are robust to country-level clustering. Year dummies and cubic function of lagged total BIT participation as well as lags of ratification also included but coefficients not reported. All other controls are lagged one year.

\section{OTher Robustness Tests}

Table A3 shows the robustness of the strong negative impact of BIT claims on participation to plausible changes in the base specification. In column 1 the controls for FDI flows are omitted from the base specification. If BITs have some impact on FDI flows, it is possible that including FDI on the right-hand side could bias all the coefficients in the regression. Furthermore, including FDI on the right-hand side may cause bias due to nonrandom missing values in the FDI data. However, the economically and statistically insignificant difference between the coefficients on BIT claim in column 1 and the base regression suggest neither endogeneity nor selection bias problems in the base regression.

Column 2 omits all lagged BIT participation controls. The robustness of the result here confirms that the negative BIT claim effect is not a spurious time-series artifact due to the lagged participation controls. Column 3 omits the year dummies from the base specification and instead includes global BIT participation and claims. As we would expect, the total number of BITs signed globally is positively related to partici- 
pation, while the impact of increasing total global claims is negative. Columns 4 and 5 add to the base specification respectively controls for non-BIT investor-state arbitrations (that is, with jurisdiction based on national investment laws or other investment treaties) and BIT claims where investors sought more than US $\$ 100$ million in compensation. Controlling for non-BIT claims has negligible effect on the base regression. Controlling for large BITclaims (in column 5) substantially reduces the coefficient on all BIT claims. This makes sense, as the coefficient on all BIT claims should now be interpreted as the response to small, medium, or publicly unknown magnitude claims.

\section{TABLE A3}

Strong Negative Effect of Claims on Participation Is Robust to DifFerent Specifications, Including Controlling for Large BIT Claims and Non-BIT Investor Claimsa

\begin{tabular}{|c|c|c|c|c|c|}
\hline & (1) & (2) & (3) & (4) & (5) \\
\hline L.BIT Claim & $\begin{array}{c}-0.436^{* * * *} \\
(0.102)\end{array}$ & $\begin{array}{c}-0.441^{* * * *} \\
(0.107)\end{array}$ & $\begin{array}{c}-0.465^{* * * *} \\
(0.110)\end{array}$ & $\begin{array}{l}-0.421^{* * * *} \\
(0.107)\end{array}$ & $\begin{array}{c}-0.365^{* * * *} \\
(0.120)\end{array}$ \\
\hline L.GDP & $\begin{array}{c}0.000 \\
(0.000)\end{array}$ & $\begin{array}{l}0.001^{* * * * *} \\
(0.000)\end{array}$ & $\begin{array}{c}0.001^{* *} \\
(0.001)\end{array}$ & $\begin{array}{c}0.001^{* *} \\
(0.001)\end{array}$ & $\begin{array}{c}0.001^{* *} \\
(0.001)\end{array}$ \\
\hline L.Invest.Protect & $\begin{array}{l}0.073^{* * * *} \\
(0.021)\end{array}$ & $\begin{array}{l}0.064^{* * * *} \\
(0.022)\end{array}$ & $\begin{array}{c}0.046^{* * *} \\
(0.021)\end{array}$ & $\begin{array}{l}0.071^{\text {*** }} \\
(0.022)\end{array}$ & $\begin{array}{l}0.071^{* * *} \\
(0.022)\end{array}$ \\
\hline L.Inward FDI & & $\begin{array}{c}-0.018^{*} \\
(0.011)\end{array}$ & $\begin{array}{c}-0.010 \\
(0.010)\end{array}$ & $\begin{array}{c}-0.016 \\
(0.011)\end{array}$ & $\begin{array}{c}-0.015 \\
(0.011)\end{array}$ \\
\hline L.Outward FDI & & $\begin{array}{c}-0.011 \\
(0.014)\end{array}$ & $\begin{array}{c}-0.011 \\
(0.014)\end{array}$ & $\begin{array}{c}-0.012 \\
(0.014)\end{array}$ & $\begin{array}{c}-0.011 \\
(0.014)\end{array}$ \\
\hline Global BITs & & & $\begin{array}{l}0.001^{\text {**** }} \\
(0.000)\end{array}$ & & \\
\hline Global Claims & & & $\begin{array}{c}-0.004^{* * * *} \\
(0.001)\end{array}$ & & \\
\hline L.Non-BIT Claim & & & & $\begin{array}{c}0.182 \\
(0.188)\end{array}$ & \\
\hline L.Big BIT Claim & & & & & $\begin{array}{c}-0.169 \\
(0.166)\end{array}$ \\
\hline Constant & $\begin{array}{l}1.603^{* * *} \\
(0.434)\end{array}$ & $\begin{array}{l}1.339^{* * * *} \\
(0.318)\end{array}$ & $\begin{array}{l}0.437^{* * *} \\
(0.215)\end{array}$ & $\begin{array}{c}2.234^{* * * *} \\
(0.494)\end{array}$ & $\begin{array}{c}2.203^{* * * *} \\
(0.495)\end{array}$ \\
\hline Observations & 1832 & 1604 & 1604 & 1604 & 1604 \\
\hline
\end{tabular}

${ }^{*} p<0.10,{ }^{* *} p<0.05,{ }^{* * *} p<0.01$

${ }^{\text {a }}$ Dependent variable is the annual number of BITs signed. Table reports coefficients from negative binomial, fixed-effect estimation, standard errors in parentheses. Year dummies (except in column 3) and cubic function of lagged total BIT participation as well as lags of ratification (except in column 2) also included but coefficients not reported. All other controls are lagged one year. 
Table A4 repeats the exercise of Table 7 using the data set from an important recent contribution to the literature by Jandhyala, Henisz, and Mansfield..$^{98}$ In column 1 we see once again that our principal finding of a strong negative impact from first claim against a host is robust to the use of a bilateral/dyadic modeling approach. In column 2 we add the variable for first claim brought by an investor from the potential host country, and once again see no effect from this variable. In columns 3 and 4 we make the specification increasingly conservative by adding first-year and then host-country dummies. In all cases we find strong evidence that hosts decrease participation in response to the first claim against them but show no response to the first claim brought by investors from the potential host.

\section{TABLE A4}

Using the Data Set of Jandhyala, Henisz, and Mansfield 2011 (JHM), We see Robust Evidence That Claims against Host Significantly Reduce LiKelihood of BIT Formation while Claims by Investors from Partner Have No EfFecta ${ }^{a}$

\begin{tabular}{lcccc}
\hline \hline & $(1)$ & $(2)$ & $(3)$ & $(4)$ \\
\hline BIT Claim against (Host) & $0.621^{+*+*}$ & $0.569^{+*+}$ & $0.651^{+*+}$ & $0.584^{+*+}$ \\
& $(0.055)$ & $(0.052)$ & $(0.061)$ & $(0.066)$ \\
BIT Claim by (Source) & & 0.908 & 0.981 & 1.023 \\
& & $(0.081)$ & $(0.093)$ & $(0.092)$ \\
Observations & 145287 & 123729 & 123729 & 123729 \\
Quadratic in Host no. of BITs & yes & yes & yes & yes \\
Quadratic in Source no. of BITs & no & yes & yes & yes \\
Year Dummies & no & no & yes & yes \\
Host Country Dummies & no & no & no & yes \\
\hline
\end{tabular}

" $p<0.10, "$ " $p<0.05, "$ "' $p<0.01$

${ }^{a}$ Exponentiated coefficients of piecewise exponential model of BIT signing, standard errors in parentheses. Data set and regression specification are exactly as per column 1 of Table 2 of JHM 2011 except for our extra controls as indicated in the table. Full set of results showing coefficients for all variables in the regression is available from the authors upon request.

\section{REFERENCES}

Aaken, Anne Van. 2010. "The International Investment Protection Regime through the Lens of Economic Theory." In Michael Waibel, Asha Kaushal, Kyo-Hwa Chung, and Claire Balcin, eds., The Backlash against Investment Arbitration. Alphen aan den Rijn, Netherlands: Kluwer Law International.

${ }^{98}$ JHм 2011. 
Abdelal, Rawi, Mark Blyth, and Craig Parsons. 2010. "Introduction: Constructing the International Economy." In Rawi Abdelal, Mark Blyth, and Craig Parsons, eds., Constructing the International Economy. Ithaca, N.Y.: Cornell University Press.

Aisbett, Emma. 2009. "Bilateral Investment Treaties and Foreign Direct Investment: Correlation versus Causation.” In Karl Sauvant and Lisa Sachs, eds., The Effect of Treaties on Foreign Direct Investments. New York, N.Y.: Oxford University Press.

Allee, Todd, and Clint Peinhardt. 2010. "Delegating Differences: Bilateral Investment Treaties and Bargaining over Dispute Resolution Provisions." International Studies Quarterly 54, no. 1: 1-26.

- 2011. "Contingent Credibility: The Impact of Investment Treaty Violations on Foreign Direct Investment." International Organization 65, no. 3: 401-32.

Allison, Paul, and Richard Waterman. 2002. "Fixed-Effects Negative Binomial Regression Models.” Sociological Methodology 32, no. 1: 247-65.

Alvarez, Jose. 2011. The Public International Law Regime Governing International Investment. The Hague, Netherlands: Hague Academy of International Law.

Arellano, Manuel, and Bo Honoré. 2001. "Panel Data Models: Some Recent Developments." In James Heckman and Edward Leamer, eds., Handbook of Econometrics, vol. 5. Amsterdam, Netherlands: Elsevier.

Beck, Thorsten, George Clarke, Alberto Groff, Philip Keefer, and Patrick Walsh. 2001. "New Tools in Comparative Political Economy: The Database of Political Institutions." World Bank Economic Review 15, no. 1: 165-76.

Blake, Daniel. 2010. "Thinking Ahead: Time Horizons and the Legalization of International Investment Agreements.” Working Paper.

Bubb, Ryan, and Susan Rose-Ackerman. 2007. "BITs and Bargains: Strategic Aspects of Bilateral and Multilateral Regulation of Foreign Investment." International Review of Law and Economics 27: 291-311.

Busch, Marc, Eric Reinhardt, and G. Shaffer. 2009. "Does Legal Capacity Matter? A Survey of WTO Members.” World Trade Review 8, no. 4: 559-77.

Büthe, Tim, and Helen Milner. 2009. "Bilateral Investment Treaties and Foreign Direct Investment." In Karl Sauvant and Lisa Sachs, eds., The Effect of Treaties on Foreign Direct Investment: Bilateral Investment Treaties, Double Taxation Treaties, and Investment Flows. New York, N.Y.: Oxford University Press.

Camerer, Colin. 2004. Behavioural Game Theory. Princeton, N.J.: Princeton University Press.

Camerer, Colin, and Howard Kunreuther. 1989. "Decision Processes for Low Probability Events: Policy Implications." Journal of Policy Analysis and Management 8, no. 4: 565-92.

Camerer, Colin, George Loewenstein, and Matthew Rabin, eds. 2003. Advances in Behavioral Economics. Princeton, N.J.: Princeton University Press.

Conlisk, John. 1996. "Why Bounded Rationality?” Journal of Economic Literature 34, no. 2: 669-700.

Department of Trade and Industry (DTI), Republic of South Africa. 2009. Government Position Paper on Bilateral Investment Treaty Policy Framework Review.

Elkins, Zachary, Andrew Guzman, and Beth Simmons. 2006. "Competing for Capital: The Diffusion of Bilateral Investment Treaties, 1960-2000." International Organization 60, no. 4: 811-46. 
- 2010. "Replication Data for: Competing for Capital: The Diffusion of Bilateral Investment Treaties, 1959-2000."

Elms, Deborah. 2000. "New Directions for IPE: Drawing from Behavioural Economics." International Studies Review 10, no. 2: 239-65.

Gilardi, Fabrizio, Katharina Füglister, and Stéphane Luyet. 2009. "Learning from Others: The Diffusion of Hospital Financing Reforms in OECD Countries." Comparative Political Studies 42, no. 4: 549-73.

Guzman, Andrew. 1998. "Why LDCs Sign Treaties That Hurt Them: Explaining the Popularity of Bilateral Investment Treaties." Virginia Journal of International Law 38, no. 4: 639-88.

Hafner-Burton, Emilie, Alex Hughes, and David Victor. 2011. "The Behavioral Psychology of Elite Decision Making: Implications for Political Science.” ILAR Working Paper no. 19.

Hafner-Burton, Emilie, Brad Leveck, David Victor, and James Fowler. 2012. "A Behavioural Approach to International Legal Cooperation.” ILAR Working Paper no. 13.

Haftel, Yoram, and Alexander Thompson. 2012. "Why Do States Renegotiate International Agreements? The Case of Bilateral Investment Treaties." Working Paper.

Hausman, Jerry, Bronwyn Hall, and Zvi Griliches. 1984. "Econometric Models for Count Data with an Application to the Patents-R\&D Relationship." Econometrica 52, no. 4: 909-38.

Healy, Andrew, and Neil Malhotra. 2009. "Myopic Voters and Natural Disaster Policy.” American Political Science Review 103, no. 3: 387-406.

Herrera, Yoshiko. 2007. Imagined Economies: The Sources of Russian Regionalism. Cambridge, UK: Cambridge University Press.

Highhouse, Scott, Susan Mohammed, and Jody Hoffman. 2010. "Temporal Discounting of Strategic Issues: Bold Forecasts for Opportunities and Threats." Basic and Applied Social Psychology 24, no. 1: 43-56.

Hsu, Locknie. 2006. "MFN and Dispute Settlement: When the Twain Meet." Journal of World Investment and Trade 7, no. 1: 25-37.

Jandhyala, Srividya, Witold Henisz, and Edward Mansfield. 2011. "Three Waves of BITs: The Global Diffusion of Foreign Investment Policy.” Journal of Confict Resolution 55, no. 6: 1047-73.

Jervis, Robert. 1976. Perception and Misperception in International Politics. Princeton, N.J.: Princeton University Press.

Johnson, Eric, John Hershey, Jacqueline Meszaros, and Howard Kunreuther. 2000. "Framing, Probability Distortions, and Insurance Decisions." In Daniel Kahneman and Amos Tversky, eds., Choices, Values and Frames. New York, N.Y.: Cambridge University Press.

Jones, Bryan. 1999. "Bounded Rationality." Annual Review of Political Science 2, no. 1: 297-321.

Jones, Bryan, and Frank Baumgartner. 2005. The Politics of Attention. Chicago, Ill.: University of Chicago Press.

Jupille, Joseph, Walter Mattli, and Duncan Snidal. Forthcoming. Institutional Choice in Global Commerce. Cambridge, UK: Cambridge University Press.

Krebs, Ronald, and Aaron Rapport. 2012. "International Relations and the Psychology of Time Horizons." International Studies Quarterly 56, no. 3: 1468-78. 
Kunreuther, Howard, Robert Meyer, Richard Zeckhauser, Paul Slovic, Barry Schwartz, Christian Schade, Mary Luce, Steven Lippman, David Krantz, Barbara Kahn, and Robin Hogarth. 2002. "High Stakes Decision Making: Normative, Descriptive and Prescriptive Considerations." Marketing Letters 13, no. 3: 259-68.

Lake, David. 2009. "Open Economy Politics: A Critical Review." Review of International Organizations 4, no. 3: 219-44.

Legum, Barton. 2006. "Defining Investment and Investor: Who Is Entitled to Claim?” Arbitration International 22, no. 4: 521-26.

Levy, Jack. 1994. "Learning and Foreign Policy: Sweeping a Conceptual Minefield.” International Organization 48, no. 2: 279-312.

Mangklatanakul, Vilawan. 2011. "Thailand's First Treaty Arbitration: Gain from Pain." In UNCTAD, Investor-State Disputes: Prevention and Alternatives to Arbitration II. Geneva, Switzerland: United Nations.

March, James. 2010. The Ambiguities of Experience. Ithaca, N.Y.: Cornell University Press.

McClelland, Gary, William Schulze, and Don Coursey. 1993. "Insurance for Low-Probability Hazards: A Bimodal Response to Unlikely Events.” Journal of Risk and Uncertainty 7, no. 1: 95-116.

McDermott, Rose. 2004. Political Psychology in International Relations. Ann Arbor, Mich.: University of Michigan Press.

Meseguer, Covadonga. 2006. "Rational Learning and Bounded Rational Learning in the Diffusion of Policy Innovations." Rationality and Society 18, no. 1: 35-66.

- 2009. Learning, Policy Making, and Market Reforms. Cambridge, UK: Cambridge University Press.

Montt, Santiago. 2009. State Liability in Investment Treaty Arbitration: Global Constitutional and Administrative Law in the BIT Generation. Oxford, UK: Hart Publishing.

Neale, Margaret, and Max Bazerman. 1991. Cognition and Rationality in Negotiations. New York, N.Y.: Free Press.

Odell, John. 2002. "Bounded Rationality and the World Political Economy: The Nature of Decision Making." In David Andrews, C. Randall Henning, and Louis Pauly, eds., Governing the World's Money. Ithaca, N.Y.: Cornell University Press.

Parra, Antonio. 1996. "Scope of New Investment Laws and International instruments." Dawn. October 9, 10, 11, and 12.

Parlett, Kate 2011. The Individual in the International Legal System: Continuity and Change in International Law. Cambridge, UK: Cambridge University Press.

Pinto, Pablo, Santiago Pinto, and Nicolás Stier-Moses. 2011. "Regulating Foreign Investment: A Study of the Properties of Bilateral Investment Treaties." Working Paper.

Poulsen, Lauge. 2010. "The Importance of BITs for Foreign Direct Investment and Political Risk Insurance: Revisiting the Evidence.” In Karl Sauvant, ed., Yearbook on International Investment Law and Policy 2009/2010. New York, N.Y.: Oxford University Press.

- 2014. "Bounded Rationality and the Diffusion of Modern Investment Treaties.” International Studies Quarterly 58, no. 1.

Ranjan, Prabhash. 2012. "International Investment Agreements and India's Regulatory Power as a Host Nation.” Ph.D. diss., Kings College. 
Reiter, Dan. 1996. Crucible of Beliefs: Learning, Alliances, and World Wars. Ithaca, N.Y.: Cornell University Press.

Saban, Daniela, Flavia Bonomo, and Nicolás Stier-Moses. 2010. "Analysis and Models of Bilateral Investment Treaties Using a Social Networks Approach.” Physica A: Statistical Mechanics and Its Applications 389, no. 17: 3661-73.

Salacuse, Jeswald. 1990. "BIT by BIT: The Growth of Bilateral Investment Treaties and Their Impact on Foreign Investment in Developing Countries." International Lawyer 24, no. 3: 655-75.

Schill, Stefan. 2009. The Multilateralization of International Investment Law. Cambridge, UK: Cambridge University Press.

Schneiderman, David. 2008. Constitutionalizing Economic Globalization: Investment Rules and Democracy's Promise. Cambridge, UK: Cambridge University Press.

Simmons, Beth, Frank Dobbin, and Geoffrey Garrett. 2006. "Introduction: The International Diffusion of Liberalism.” International Organization 60, no. 4: 781-810.

Simon, Herbert. 1957. Models of Man. New York, N.Y.: Wiley.

Slovic, Paul, Baruch Fischhoff, Sarah Lichtenstein, Bernard Corrigan, and Barbara Combs. 2000. "Preference for Insuring against Probable Small Losses: Insurance Implications.” In Paul Slovic, ed., The Perception of Risk. London, UK: Earthscan.

Slovic, Paul, Baruch Fischhoff, and Sarah Lichtenstein. 2000a. "Rating the Risks." In Paul Slovic, ed., The Perception of Risk. London, UK: Earthscan.

- 2000b. "Accidental Probabilities and Seat Belt Usage: A Psychological Perspective.” In Paul Slovic, ed., The Perception of Risk. London, UK: Earthscan.

Slovic, Paul, Howard Kunreuther, and Gilbert White. 2000. "Decision Processes, Rationality and Adjustment to Natural Hazards." In Paul Slovic, ed., The Perception of Risk. London, UK: Earthscan.

Steinbrugge, Karl, Frank McClure, and A. Snow. 1969. "Studies in Seismicity and Earthquake Damage Statistics.” Washington, D.C.: United States Department of Commerce.

Sunstein, Cass, ed. 2000. Behavioral Law and Economics. Cambridge, UK: Cambridge University Press.

Thaler, Richard, ed. 2005. Advances in Behavioral Finance, vol. 2. Princeton, N.J.: Princeton University Press.

Tversky, Amos, and Daniel Kahneman. 1973. "Availability: A Heuristic for Judging Frequency and Probability." Cognitive Psychology 5, no. 2: 207-32.

United Nations Conference on Trade and Development (UNCTAD). 1998. Bilateral Investment Treaties in the Mid-1990s. Geneva, Switzerland: United Nations.

- 1999. Trends in International Investment Agreements: An Overview. Geneva, Switzerland: United Nations.

- 2002. Progress Report: Work Undertaken within UNCTAD's Work Programme on International Investment Agreements between the 10th Conference of UNCTAD, Bangkok, February 2000 and July 2002. Geneva,Switzerland: United Nations. 
2007. Investor-State Dispute Settlement and Impact on Investment Rulemaking. Geneva, Switzerland: United Nations.

United Nations Centre on Transnational Corporations (UNCTC). 1988. Bilateral Investment Treaties. New York, N.Y.: United Nations.

Van Harten, Gus. 2007. Investment Treaty Arbitration and Public Law. Oxford, UK: Oxford University Press.

- 2010. "Five Justifications for Investment Treaties: A Critical Discussion." Trade, Law and Development 2, no. 1: 19-58.

Vertzberger, Yaacov. 1998. Risk-Taking and Decision Making: Foreign Military Intervention Decisions. Stanford, Calif.: Stanford University Press.

Wakslak, Cheryl, and Yaacov Trope. 2009. "The Effect of Construal Level on Subjective Probability Estimates.” Psychological Science 20, no. 1: 52-58.

Wälde, Thomas. 2005. "The 'Umbrella' Clause in Investment Arbitration: A Comment on Original Intentions and Recent Cases." Journal of World Investment and Trade 6, no. 2: 183-236.

Walter, Stefanie, and Thomas Willett. 2011. "Delaying the Inevitable: A Political Economy Approach to Currency Defences and Depreciation." Review of International Political Economy 19, no. 1: 114-39.

Weyland, Kurt. 2006. Bounded Rationality and Policy Diffusion: Social Sector Reform in Latin America. Princeton, N.J.: Princeton University Press.

- 2009. "The Diffusion of Revolution: '1848' in Europe and Latin America." International Organization 62, no. 3: 391-423.

- 2010. "The Diffusion of Regime Contention in European Democratization, 1830-1940." Comparative Political Studies 43, no. 8-9: 1148-76.

Yackee, Jason. 2008. "Conceptual Difficulties in the Empirical Study of Bilateral Investment Treaties.” Brooklyn Journal of International Law 33, no. 2: 405-41. 